\title{
Tarihi Yarımada İnşaat İşlerinde Arkeolojik Kazı İmalatlarının Süre ve Maliyete Etkisi: Vaka Analizi
}

\author{
Case Study: Effect of Archaeological Excavation on Time and Cost in Historical Peninsula \\ Construction Works
}

\section{Cemil Akçay* ${ }^{\circledR}$}

Öz

İstanbul zaman içerisinde birçok medeniyete ev sahipliği yapmıştır. Geçmişten günümüze miras olarak gelen tarihî yapı ve alanlar düşünüldüğünde İstanbul'da Tarihi Yarımada bir diğer adıyla Sur İçi ön plana çıkmaktadır. Günümüzde Fatih ilçe sınırları içerisinde kalan bölge ile Yenikapı Dolgu Alanı́nın olduğu alan Tarihi Yarımada'yı oluşturmaktadır. Yüzlerce tescilli eserin bulunduğu bu bölgede ayrıca Unesco Dünya Miras listesine giren tarihî alanlar da bulunmaktadır. Bölgenin büyük çoğunluğu Kentsel-Tarihi sit alanıdır. Roma, Bizans ve Osmanlı İmparatorluğu gibi büyük medeniyetlere başkentlik yapmış olan bölgenin savaşlar neticesinde el değiştirmesi birçok sivil mimarlık örneği yapının yıkılması ve toprak altında kalmasına sebep olmuştur. Bu sebeple bölgede yürütülen inşaat işlerinde söz konusu kültür tabakalarına zarar verilmemesi için İstanbul Arkeoloji Müze Müdürlüğü denetiminde arkeolojik araştırma kazıları yapılmaktadır. Kazıda, taşınır ve taşınmaz kültür varlığına rastlanılması durumunda ilgili Kültür Varlıkları Koruma Bölge Kurul kararları doğrultusunda, kültür varlıklarının tescili ve korunması veya kaldırılması söz konusu olmaktadır. Yine, bölgede benzer şekilde iksa sistemi olarak kuyu temel iksa sistemi yapılmakta ve bunların kazıları da arkeolojik kazı olarak gerçekleştirilmektedir. Tarihi Yarımada'da gerçekleştirilen inşaatlarda uygulanan arkeolojik kazı ve kuyu temel iksa sistemleri, inşaat maliyetlerini arttırmakta ve inşaatların tamamlanma süresini uzatmaktadır. Bölgedeki örnek bir proje üzerinden yola çıkılarak hazırlanan bu çalışmada arkeolojik kazı ve kuyu temel imalatlarının süre ve maliyete etkisi incelenmiştir. Aynı yapının bu bölgede arkeolojik kazı ile yapılması ile başka bir bölgede normal inşaat teknikleriyle yapılması; maliyet çalışması, kritik yol ile iş planı yapılması ve $S$ eğrileri ile bütçeleme yapılması teknikleri doğrultusunda kıyaslanarak söz konusu etkiler ortaya konulmuştur.

\section{Anahtar Kelimeler}

Arkeolojik Kazı, Süre, Maliyet, Kuyu Temel, Kritik Yol Metodu

\section{Abstract}

Throughout history, Istanbul has hosted several civilizations. The historical Peninsula, also known as Sur İçi, stands out in Istanbul because of its historical buildings and areas that have been inherited from past generations. The historical Peninsula is located within the borders of the Fatih district and the Yenikapı Filling area. In this region, hundreds of registered works are located and historical sites included in the UNESCO World Heritage list are also found. The region's Urban-Historical sites constitute the vast majority of the region. Numerous examples of civic architecture were razed and sunk under the ground as the region, which was the capital of great civilizations such as the Roman, Byzantine, and Ottoman empires, changed hands due to wars. Therefore, archaeological research excavations are conducted under the Museum Directorate's supervision to avoid damage to existing cultural elements during construction works in the region. When movable and immovable cultural assets are discovered during excavation, they are either are registered

* Sorumlu Yazar: Cemil Akçay (Dr. Öğr. Üyesi), İstanbul Üniversitesi, Mimarlık Fakültesi, Mimarlık Bölümü, İstanbul, Türkiye. E-posta: cakcay@istanbul.edu.tr, ORCID: 0000-0002-8216-8688

Atıf: Akcay, Cemil. "Tarihi Yarımada İnşaat İşlerinde Arkeolojik Kazı İmalatlarının Süre ve Maliyete Etkisi: Vaka Analizi." Art-Sanat, 16(2021): 1-29. https://doi.org/10.26650/artsanat.2021.16.0001 
and protected or removed according to the decisions of the Cultural Heritage Preservation Board. Similarly, the region's shoring system is constructed as a well foundation and excavations are performed as archaeological excavations. The use of archaeological excavation and well foundation shoring systems in the constructions on the historic Peninsula raises construction costs and extends the completion time. This study investigates the effects of archaeological excavation and well foundation construction on time and cost based on an outstanding project in the region. These effects were revealed by comparing the archaeological excavation of the same building in this region and construction with standard construction techniques in another region, in line with cost study, a business plan with critical path, and budgeting techniques with the S-curves.

Keywords

Archaeological Excavation, Time, Cost, Well Foundation, CPM

\section{Extended Summary}

The historical Peninsula is the entire region that comprises the Fatih district and the Yenikap1 Filling area and has hosted several different civilizations throughout history, such as Rome, Byzantine, and Ottoman. Istanbul, which is located on the historical Peninsula, has served as the capital of several empires including Rome, Byzantine, and the Ottoman. "Suriçi" is another name for the historical Peninsula. When studying the region's history, the first ruins date back to prehistoric times, and the first formation of the topography dates back to 7000-8000 BC. It highlights the historical past extending back to the Roman and Byzantine empires and the Neolithic period within the purview of the Marmaray project, particularly boat remains and other archaeological findings in the excavations conducted in the Yenikap1 station area. In addition, four areas in the region are designated as Historic Areas in the UNESCO World Heritage List: Sultanahmet Protection Area, Süleymaniye Mosque, Zeyrek Mosque and its surroundings, and Istanbul Land Walls. The region's city history, e.g., Istanbul's, bears the imprints of great civilizations. Besides wars, natural disasters such as fires and earthquakes have caused the destruction and burial of architectural and artistic structures. Therefore, not degrading existing cultural components and instead highlight them during construction activities in the region is essential. First and foremost, the Sultanahmet area in the historical Peninsula was classified as an "Archaeological Park" by the High Council of Real Estate Antiquities and Monuments in 1953. Then, in 1979, Zeyrek was designated as a "Protection Area." In 1981, Süleymaniye Mosque and its environs were also registered as a "Protection Area." The Cultural Heritage Preservation Regional Board registered and declared the entire region, encompassing the old Eminönü and Fatih district borders, as a protected area in 1985. Moreover, in line with the region's development, renewal areas have been established under Law No. 5366 on the "Protection and Reconstruction of Deteriorated Historical and Cultural Immovable Assets" to reconstruct and restore the renovation areas and protected areas that have eroded and lost their characteristics. Due to the city's development and the fact that existing unregistered buildings do not satisfy the earthquake regulations criteria in practice, it is now required to perform construction activities in the historical Peninsula and accelerate this process, like Istanbul. In addition to restoring 
existing registered works to their original state, unregistered buildings are renewed as part of a master plan in the renovation areas, in compliance with the Preservation Zoning Plans approved by the Cultural Heritage Preservation Boards. The Cultural Heritage Preservation Boards also assess the relationship between new or renovated and the registered buildings in the region. First, archaeological foundation research excavations are conducted in the historic Peninsula during the construction, under the supervision of the Archaeological Museums (assigned in line with the project approved by the board. A set of rules governs construction activities in the historic Peninsula. Conservation Zoning Plans approved by the Cultural Heritage Preservation Regional Boards govern construction in urban and historical sites. The region's renewal areas are implemented according to the zoning plans and the preliminary island projects prepared by the relevant municipality and approved by the Regional Preservation Boards. Construction works in the region begin with archaeological research excavations supervised by the General Directorate of Istanbul Archaeological Museums. Construction works continue when no movable or immovable cultural property is found from the research excavations. If immovable cultural assets are located, surveys of the immovable properties are drawn up, and the Cultural Heritage Preservation Boards decide whether they will be preserved. Following the abovementioned decisions, it will be decided if the construction projects will be implemented or revised. The cost of undertaking construction work in the region has increased because of these projects. The construction period has also lengthened. Employers and contractors who will perform the job must plan ahead of time to account for this circumstance.

This study explores the effects of archaeological research excavations and well foundation constructions on the duration and cost of construction work in the historical Peninsula based on the building work planning methodologies. All construction work items are scheduled on a network based on the time and priority order. The duration of the project and the periods (abundance) in which a job can be delayed without delaying next works and the project total Critical Path Method (CPM), which is a network planning method, are utilized to calculate the start and end times of the work items using forward and backward mathematical calculations. In construction projects, the project's total and time-dependent cost changes and the time-dependent changes of the resources used in the project are analyzed using the S-curves as a functional project control tool.

In this direction, an outstanding project has been handled, the majority of which is underground. Excavation and shoring-works up to the foundation level have been calculated with two alternatives in the project. In the first option, a well foundation shoring system was used for the archaeological research excavation. Bored pile and mechanized excavation productions are utilized in the second option, which will be 
employed if the construction is performed in a normal area outside this region. Construction work items, quantity, and cost analyses were conducted for both options. The network planning CPM method was adopted to calculate the construction time. The cumulative duration and costs of the two alternatives were compared with the S-curves drawn. The total cost of archaeological excavation and well foundation production was 58\% more than bored pile and machine excavation in the case examined in the study. The study also shows that the time required for archaeological excavation and well foundation construction would be $113 \%$ more than bored pile and machine excavation. 


\section{Giriş}

Tarih boyunca Roma, Bizans ve Osmanlı gibi büyük imparatorluklara ev sahipliği yapmış olan Tarihi Yarımada, denizden Haliç ve Marmara denizi, kara tarafindan ise surlarla çevrili Fatih ilçesi sınırlarında bulunan alandır." Tarihi Yarımada "Suriçi" olarak da isimlendirilmektedir. Bölgenin tarihçesi incelendiğinde ilk kalıntıların eski tarihlere dayandı ğı, topoğrafyanın ilk oluşumunun MÖ 7000-8000'li yıllara kadar geri gittiği ileri sürülmektedir. ${ }^{2}$ Marmaray ve metro projeleri kapsamında özellikle Yenikapı istasyon alanında yapılan kazılarda bulunan tekne kalıntıları ve diğer arkeolojik bulgular, Roma ve Bizans imparatorluklarının yanı sıra Neolitik döneme uzanan tarihî geçmişe 1şık tutmuştur. ${ }^{3}$ UNESCO Dünya Mirası Komitesi tarafından Tarihi Yarımada'dan dört bölge; 1.Sultanahmet Kentsel Arkeolojik Koruma Alanı 2.Süleymaniye Camii ve Çevresi Koruma Alanı, 3. Zeyrek Camii ve Çevresi Koruma Alanı, 4. İstanbul Kara Surları Koruma Alanı "İstanbul'un Tarihi Alanları" başlığı altında 1985 yılında Dünya Mirası Listesine eklenmiştir (G. 1). ${ }^{4}$

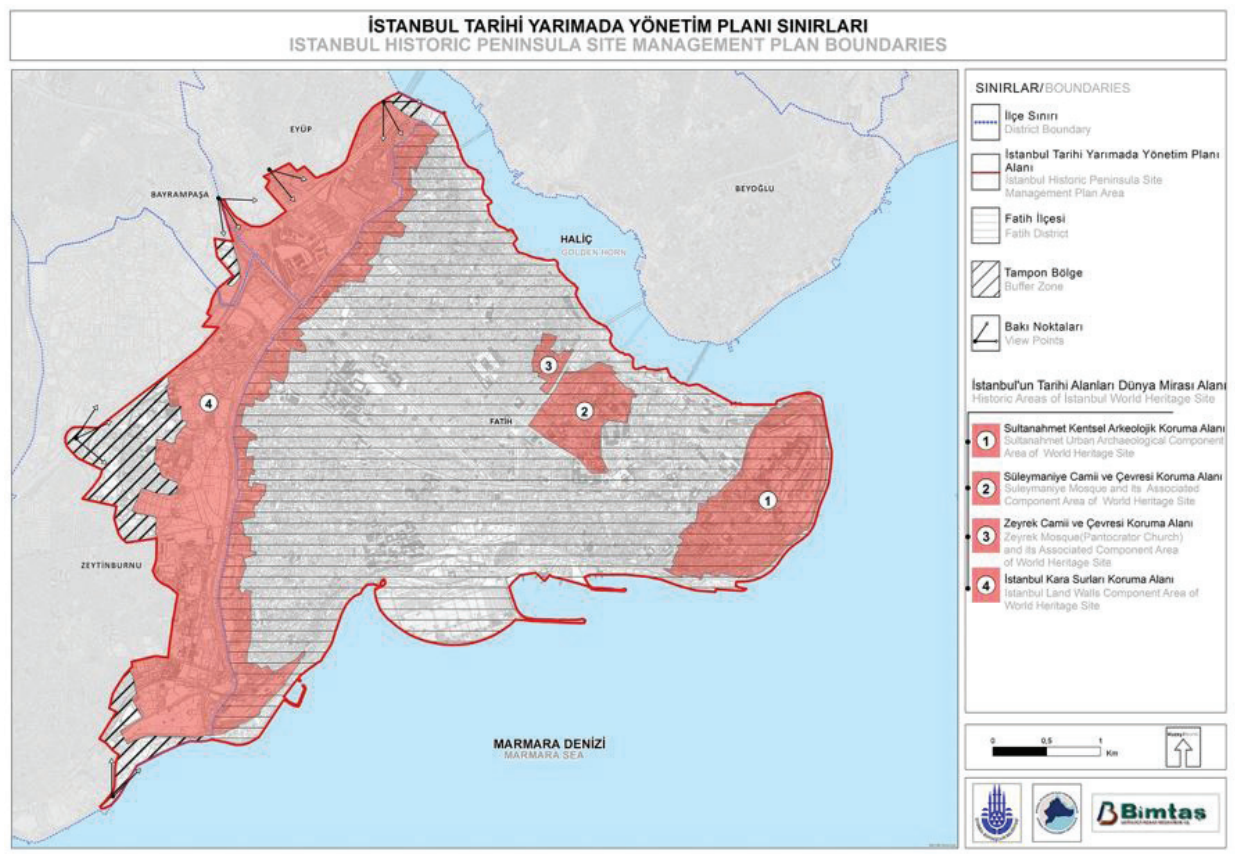

G. 1: Tarihi Yarımada Dünya Mirası Listesindeki Tarihi Alanlar (Yönetim Planı, Mayıs 2018, İBB)

1 İstanbul Tarihi Yarımada Yönetim Planı, (İstanbul: İBB ve T.C. Kültür ve Turizm Bakanlığı, 2018), 38.

2 Ufuk Esin, İstanbul'un En Eski Buluntu Yerleri ve Kültürleri, Semavi Eyice Armağanı İstanbul Yazıları, (İstanbul: Türkiye Turing ve Otomobil Kurumu, 1992), 51-71.

3 Zeynep Kızıltan, "Marmaray-Metro Projeleri ve Yenikapı Arkeolojik Kurtarma Kazıları," Colloquium Anatolicum Dergisi 13 (2014), 11-44; Zeynep Kızıltan ve Mehmet Ali Polat, "Yenikapı Kurtarma Kazıları: Neolotik Dönem Çalışmaları," Arkeoloji ve Sanat Dergisi 143 (2013), 1-40; Sait Başaran ve Ufuk Kocabaş, “Theodosius Limanı'ndan Yenikapı Batıklarına," Colloquium Anatolicum Dergisi 13 (2008), 1-22;

4 İstanbul Tarihi Yarımada Yönetim Planı, 37. 
İstanbul'un merkezi Suriçi bölgesi büyük medeniyetlerin izlerini taşımaktadır. Savaşların yanı sıra yangın ve deprem gibi doğal afetler nedeniyle özellikli mimari ve sanat yapıları yıkılarak toprak altında kalmıştır. ${ }^{5} \mathrm{Bu}$ doğrultuda bölgede yapılacak inşa faaliyetlerinde söz konusu kültür katmanlarına zarar verilmemesi ve bunların ortaya çıkarılması büyük önem arz etmektedir. Tarihi Yarımada içerisinde öncelikle 1953 yılında Gayrimenkul Eski Eserler ve Anıtlar Yüksek Kurulu tarafindan Sultanahmet Bölgesi “Arkeolojik Park” olarak belirlenmiştir. Ardından 1979 yılında Zeyrek ve 1981 yılında ise Süleymaniye Camisi ve çevresi "Koruma Alanı" olarak tescil edilmiştir. 1985 yılında ise I numaralı Kültür Varlıklarını Koruma Bölge Kurulu tarafından Fatih ilçe sınırlarını kapsayan bölgenin tamamı sit alanı olarak tescil ve ilan edilmiştir. Söz konusu kararla Tarihi Yarımada'nın tamamı Kentsel ve Tarihi sit alanı olarak tescillenmiştir. Aynı kararla Sultanahmet bölgesi Kentsel ve Arkeolojik sit alan1, Sur-u Sultani'nin (Topkapı Sarayını saran tüm surlar) içi ise I. Derece Arkeolojik sit alanı olarak belirlenmiştir. ${ }^{6}$ Söz konusu düzenleme Tarihi Yarımada Yönetim Planı Haritasında (G. 2) görülmektedir. Yönetim Planı Haritası; Ülkemiz UNESCO “Dünya Kültürel ve Doğal Mirasını Koruma Sözleşmesine imza attıktan sonra, yapılan yasal düzenlemeyle 27.10.2006 tarihinde İstanbul Büyükşsehir Belediye Başkanı oluru ile kentsel sit ve diğer sit alanlarını kapsayan bölgede kurulan İstanbul Tarihi (Sit) Alanları Yönetimi Başkanlığı tarafindan oluşturulmuştur.

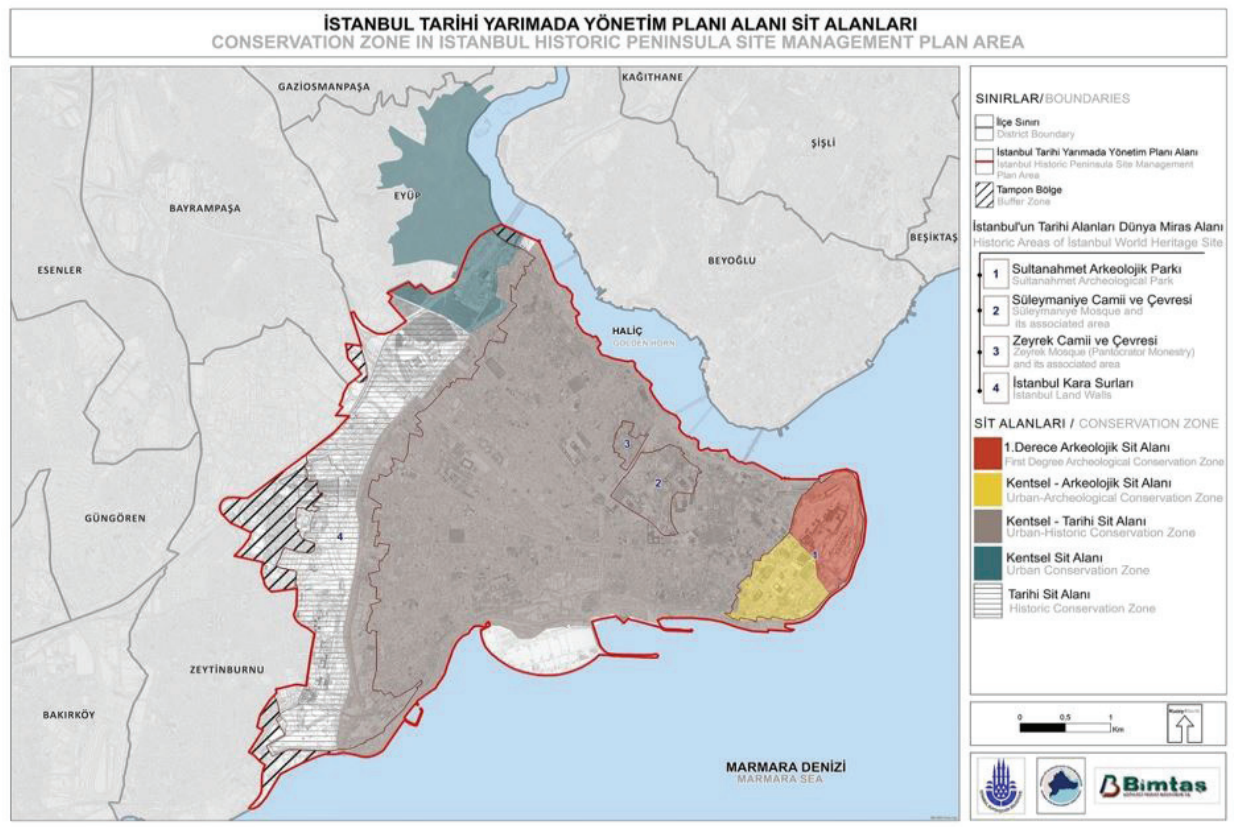

G. 2: Tarihi Yarımada Sit Alanları Düzenlemesi (Yönetim Planı, Mayıs 2018)

5 Mehmet Karakuyu, Saadet Tuğçe Tezer ve Hatice Balık, "İstanbul'un Tarihsel Topoğrafyası ve Literatür Değerlendirmesi,” Türkiye Araştırmalar Literatür Dergisi 6 (2010), 33-60.

6 Istanbul Tarihi Yarımada Yönetim Planı, 44. 
05.07.2205 tarihinde Resmi Gazete 'de yayınlanarak yürürlüğe giren 5366 sayılı yasaya göre, "Yıpranan Tarihi ve Kültürel Taşınmaz Varlıkların Yenilenerek Korunması ve Yaşatılarak Kullanılması Hakkında Kanun” ile sit alanlarında ilgisine göre il özel idareleri veya ilçe/il belediyeleri tarafindan belirlenen bölgeler için getirilen önerilerin Cumhurbaşkanınca uygun görülmesiyle "yenileme alanı” oluşturulmaktadır. ${ }^{7}$ Yenileme alanlarındaki amaç; "Yıpranan ve özelliğini kaybetmeye yüz tutmuş, sit alanı olarak tescil edilen bölgeler ile bu bölgelerin koruma alanlarının, bölgenin gelişimine uygun olarak yeniden inşa ve ihya edilmesidir. Böylelikle yenileme alanlarında konut ticari alanların yanı sıra kültür ve turizm alanları oluşturulması ve deprem gibi risklere karşı önlem alınmasıdır." "Tarihi Yarımada' da bulunan yenileme alanları haritası G. 3 'te verilmiştir.

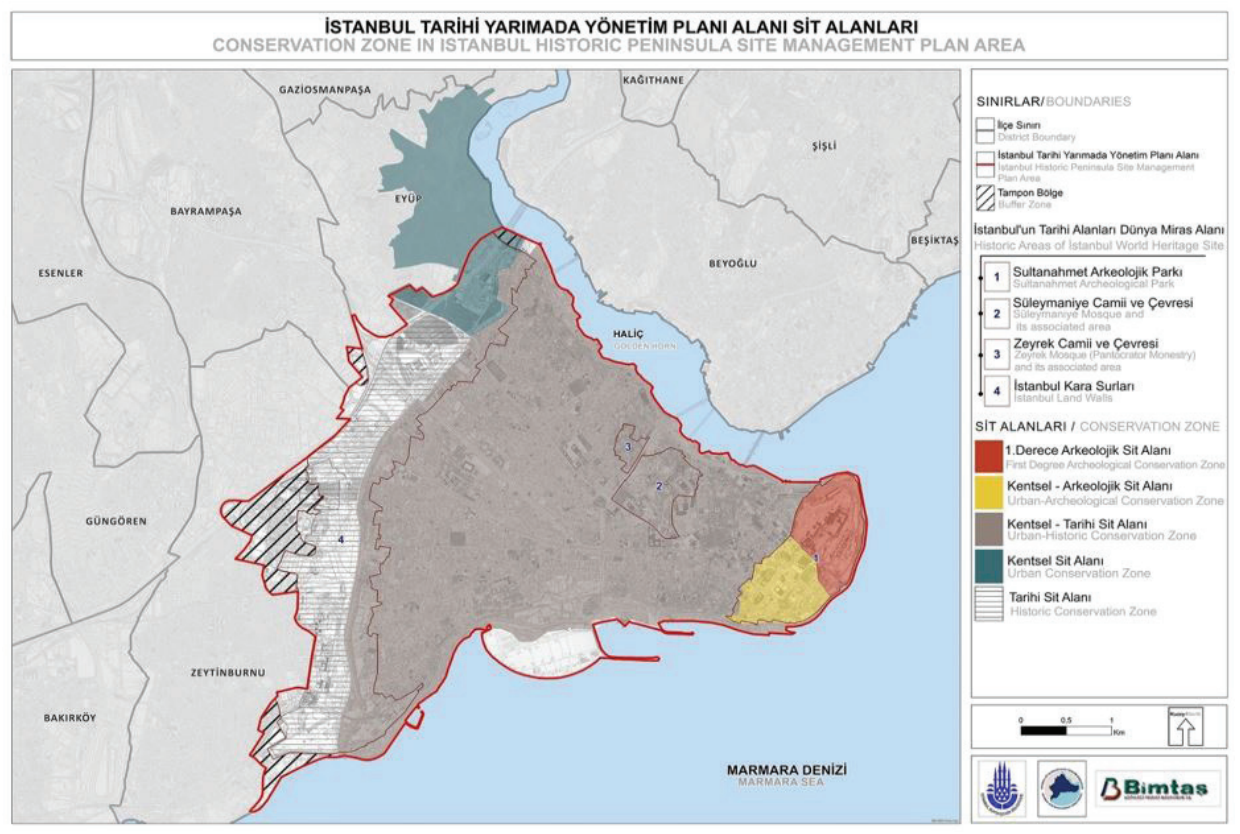

G. 3: Tarihi Yarımada Yenileme Alanları (Yönetim Planı, Mayıs 2018)

Günümüzde hem kentin gelişimi hem de mevcut tescilsiz yapıların uygulamadaki deprem yönetmeliği kriterlerini sağlamaması sebebiyle İstanbul'un genelinde olduğu gibi Tarihi Yarımada' da gerekli inşaat faaliyetlerinin gerçekleştirilmesi ve bu sürecin hızlandırılması zaruri hâle gelmiştir. Mevcut tescilli eserlerin aslına uygun bir şekilde restore edilmesinin yanı sıra, tescilsiz yapıların yenilenmesi de Kültür Varlıklarını Koruma Kurulları tarafından onaylanan Koruma Amaçlı İmar planları doğrultusunda

7 Onur Kaplan, “5366 Sayılı Kanun Kapsamında Yenileme Alanlarında Gerçekleştirilen Kentsel Dönüşüm Süreci Üzerine Bir Deneme,” Hacettepe Hukuk Fakültesi Dergisi 7 (2014), 275-304.

85366 Sayılı Kanun, Erişim 07 Mart 2021, https://www.mevzuat.gov.tr/MevzuatMetin/1.5.5366.pdf 
yenileme alanlarında Ada Avan diğer alanlarda da bir master plan çerçevesinde yapılmaktadır. Sur İçi bölgesinde onlarca tescilli tarihi yapı bulunmaktadır. Bu yapılar G. 4 'te görülmektedir.

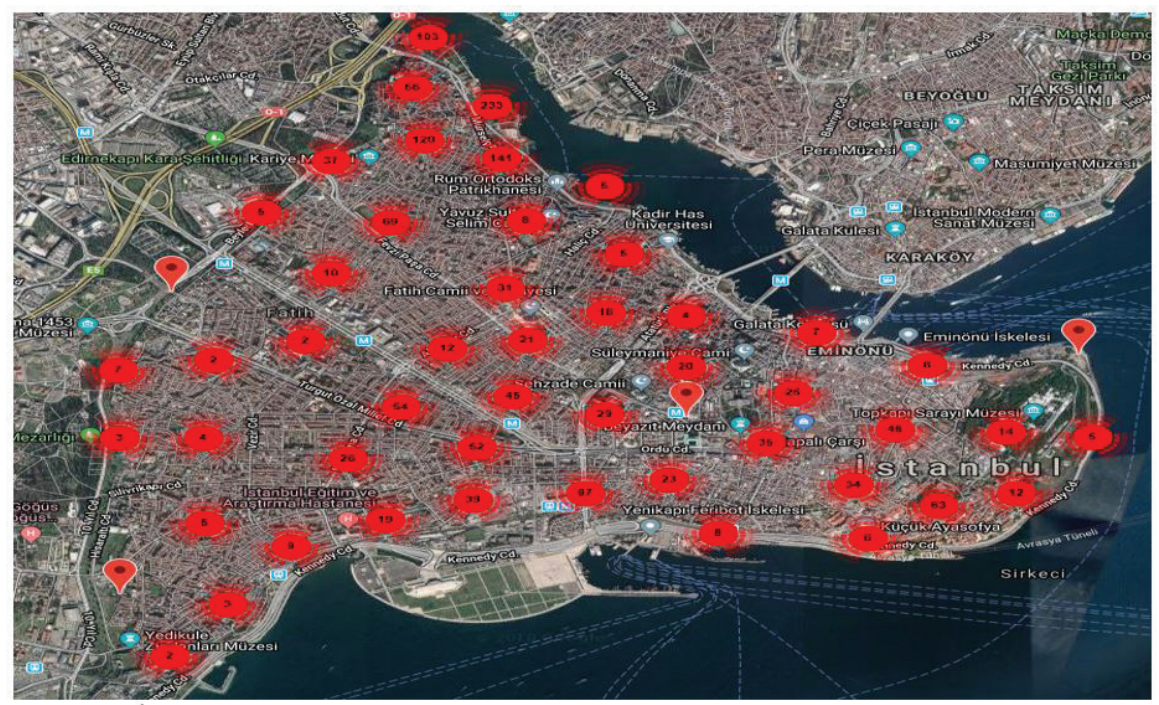

G. 4: Fatih İlçesi Kayıtlı Kültür Envanteri Haritası (http://www.envanter.gov.tr/harita/ anit?\&filtre $[61]=1105$ )

Bölgede yeni yapılacak veya yenilenecek yapıların söz konusu tescilli binalarla ilişkisi yine ilgili Kültür Varlıkları Koruma Kurullarınca değerlendirilmektedir. Tarihi Yarımada'da yapılacak yapılarda inşaat sırasında öncelikle kurul tarafindan onaylı proje doğrultusunda görevlendirilen müze denetiminde (Tarihi Yarımada'da İstanbul Arkeoloji Müzeleri Müdürlüğü) arkeolojik temel araştırma kazıları yapılmaktadır. İstanbul Arkeoloji Müzeleri'nin kuruluşu II. Abdülhamid dönemine dayanmaktadır. ${ }^{9}$ İstanbul'un kentsel planlamasında önemli bir yer tutan Âsâr-1 Âtika Nizamnamesi'nin yayınlanması ve Âsâr-1 Âtika Müzesi'nin (Eski Eserler Müzesi) kurulması bu dönemde gerçekleşmiştir. ${ }^{10}$ Tarihî inşaat işleri sırasında gerçekleştirilen arkeolojik kazılar 2863 sayılı Kültür Varlıklarını Koruma Kanunu kapsamındadır.

\section{Arkeolojik Araştırma Kazıları}

Tarihi Yarımada' da inşaat işleri Kültür Varlıklarını Koruma Kurullarınca onaylanan Koruma Amaçlı İmar Planları doğrultusunda yapılmaktadır. Bölgedeki kültür ve tabiat varlıklarının korunması bu planlar sayesinde olmaktadır. ${ }^{11}$ İnşaat işleri dolayısıyla

9 Fatih Rukancı ve Hakan Anameriç, "Arşiv Belgeleri ile II. Abdülhamid Dönemi Müzecilik Faaliyetleri," Tarih Araştırmaları Dergisi 66 (2019), 383-418.

10 Rukancı ve Anameriç, “Arşiv Belgeleri ile II. Abdülhamid Dönemi Müzecilik Faaliyetleri,” 383-418.

11 Elif Örnek Özden, "Kentsel Sit Alanı Mutlak Korunuyor Anlamına Geliyor mu," Gazi Üniversitesi Mühendislik Mimarlık Fakültesi Dergisi 4 (2006), 651-660. 
yapılacak kazı çalışmalarında Kültür Varlıklarını Koruma Kurulları, denetleme yetkisini İstanbul Arkeoloji Müzeleri Müdürlügü̈’ne (İAM) vermektedir. Müzede görevli arkeologlar denetiminde kazı çalışmaları yapılmakta ve sonuçları rapor hâlinde yine karar almak üzere ilgili koruma kurullarına gönderilmektedir.

Arkeolojik araştırma kazıları sırasında taşınır veya taşınmaz kültür varlığı çıkması durumunda bunların kaldırılıp kaldırılmayacağına Arkeoloji Müze Müdürlüğü’nün raporu doğrultusunda ilgili koruma kurulu tarafindan karar verilmektedir. Özellikle taşınmaz kültür varlığına rastlanılması durumunda bunların rölöveleri çizilmekte ve kaldırılıp kaldırılmayacağına, kaldırılmazsa mevcut projenin nasıl revize edileceğine karar verme yetkisi yine koruma kurullarındadır. Aşağıda inşaat faaliyetleri sırasında gerçekleştirilen arkeolojik kazı çalışmalarından örnekler verilecektir.

\section{1. İbrahim Efendi Konağı Arkeolojik Araştırma Kazıları}

Fatih ilçesi, Süleymaniye mahallesi, 572 ada, 51 parsel üzerinde 1913 tarihli Alman Mavisi ile 1935 tarihli Pervitich Haritaları ile 1945 yılı İstanbul Ciheti Haritası'nda var olan 1950 tarihli hava fotoğraflarında ise yıkıldığı anlaşılan İbrahim Efendi Konağı 19. yüzyıl yapısıdır (G. 5).
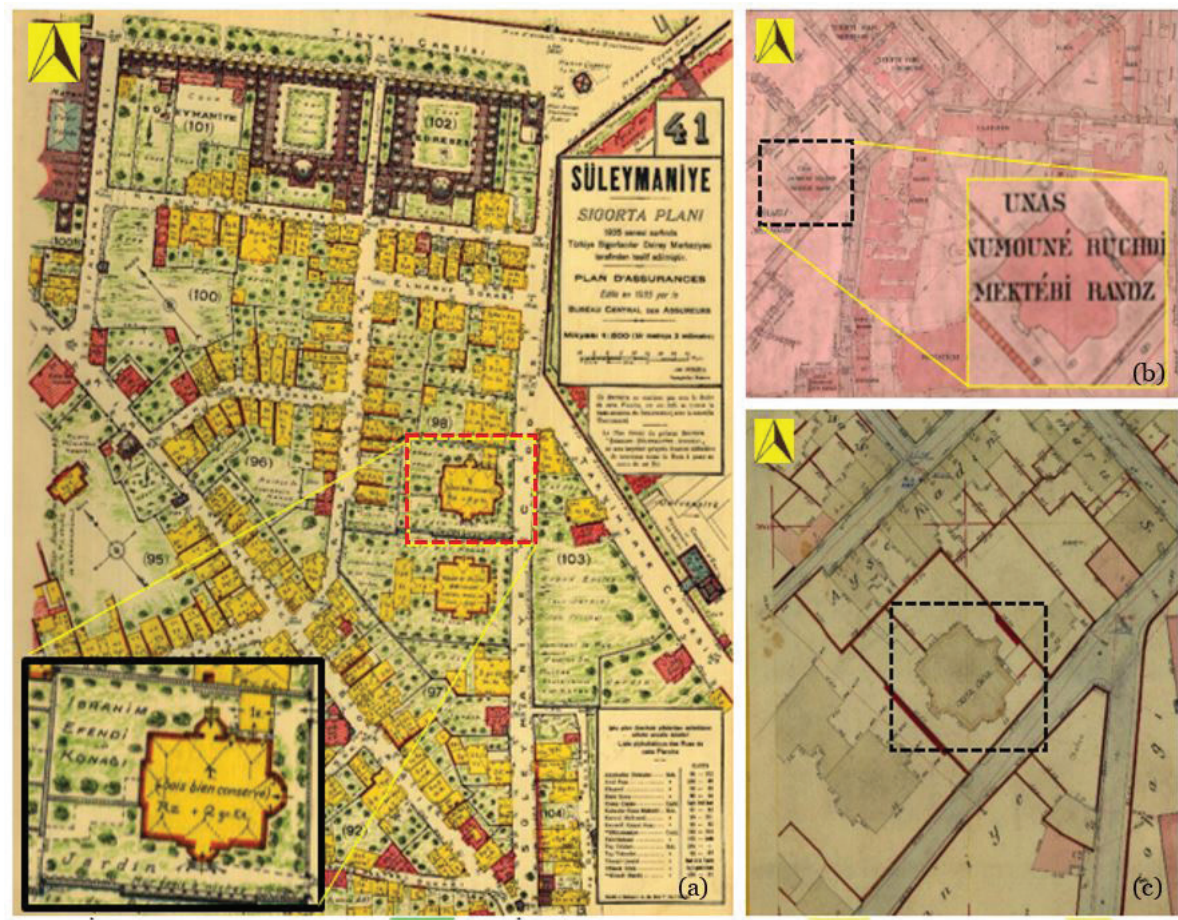

G. 5: a. Pervitich Haritası, b. Alman Mavisi, c. İstanbul Ciheti Haritası (Restitüsyon ve Rekonstrüksiyon Proje Raporu, Teb Mimarlık, 2011) 
Günümüze ulaşmayan yapının Rekonstrüksiyonu I Numaralı Yenileme Alanları Koruma Kurulu tarafindan 2010 yılında uygun görülmüş ve yapı II. Grup olarak tescil edilmiştir (18.02.2010 tarih ve 1301 say1l karar). İstanbul Arkeoloji Müzeleri Müdürlüğü denetiminde temel araştırma kazıları gerçekleştirilmiştir. Yapılan kazı çalışmalarında geç Osmanlı dönemine ait sivil mimari yapı kalıntısına rastlanmıştır (G. 6).



G. 6: Kazı Sırasında Çıkan Geç Osmanlı Dönemine Ait Kalıntı (Cemil Akçay, 2013)

Müze Müdürlüğü tarafından hazırlanan rapor ile sanat tarihi raporu doğrultusunda, plan oluşturmayan kalıntıların ilgili Kültür Varlıklarını Koruma Kurulu kararı doğrultusunda kaldırılmasına karar verilmiştir. Söz konusu alanda sadece temel araştırma kazıları değil, kuyu temeller de arkeolojik kazı olarak gerçekleştirilmiştir. Kazı işlemleri ve kalıntının kaldırılması işlemi sonucunda bina inşa edilerek Süleymaniye bölgesindeki tarihî dokuya katkı sağlanmıştır (G. 7). 




G. 7: İbrahim Efendi Konağ 1 (Cemil Akçay, 2018)

\section{2. İktisat Fakültesi Ek Bina Arkeolojik Araştırma Kazıları}

İstanbul ili, Fatih ilçesi, Süleymaniye mahallesi 102 pafta, 3036 ada, 4 parselde kayıtlı olan arazide İstanbul Üniversitesi İktisat Fakültesi ve Sosyal Bilimler Enstitüsü Yeni Bina yapımı gerçekleştirilmiştir. Çalışma kapsamında yapılan kazılarda arazinin kuzey batı kanadında Osmanlı dönemine ait bir yapı kalıntısı tespit edilmiştir. İAM denetiminde yapılan kazı çalışması ile Osmanlı dönemine ait olduğu tahmin edilen yapı kalıntısı ortaya çıkartılmıştır (G. 8). Kalıntının alt kotunda ise Bizans dönemine ait olduğu düşünülen şapel kalıntısına rastlanmıştır.
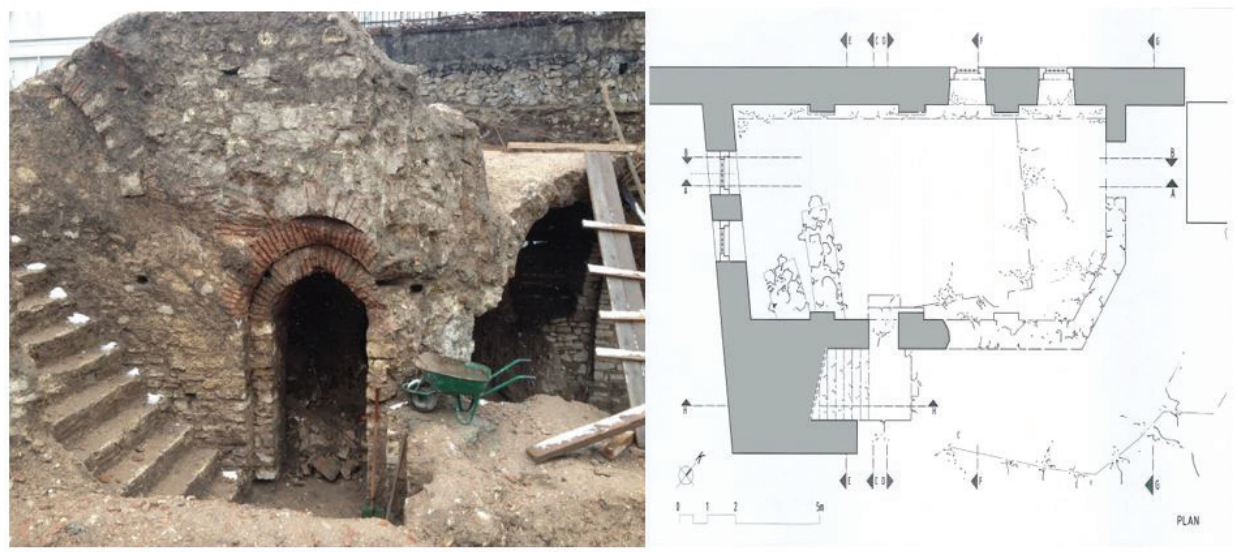

G. 8: Arkeolojik Kazı Sırasında Çıkan Kalıntı ve Rölövesi

(Tures Mimarlık -Prof. Dr. Mehmet Alper) 
Söz konusu kalıntı İAM raporu ile hazırlanan sanat tarihi raporu doğrultusunda ilgili Kültür Varlıklarını Koruma Kurulu tarafından korunması gerekli kültür varl1ğ1 olarak tescil edilmiş ve koruma grubu I olarak belirlenmiş̧ir. Yap1 projesi revize edilmiş, ortaya çıkan kalıntı koruma altına alınarak hem sergilenme hem de gelecek kuşaklara aktarılma imkânı bulmuştur (G. 9).

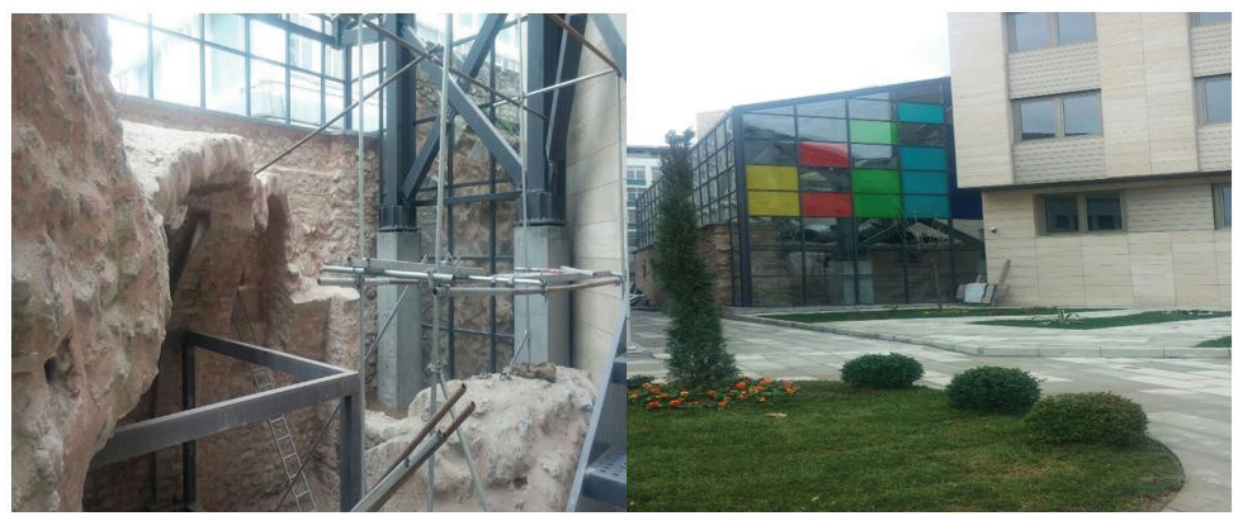

G. 9: Kalıntının Korunarak Binanın İnşası (Cemil Akçay, 2017)

\section{Yöntem}

Tarihi Yarımada'da yapılan inşaat işlerinde gerçekleştirilen arkeolojik araştırma kazısı ile kuyu temel imalatlarının süre ve maliyete etkileri, inşaat işleri planlama yöntemlerinden CPM (Critical Path Method/Kritik Yol Metodu) ile bütçeleme tekniği olan "S" eğrileri vasıtasıyla yapılmıştır.

Planlama yöntemi olan CPM ve bütçeleme tekniği olan S-eğrileri uygulamaları ile ilgili literatürde birçok çalışma bulunmaktadır. Agyei, 2015'te yaptığı çalışmada; CPM ve PERT teknikleri kullanarak bir bina projesini tamamlamak için gerekli olacak maliyet ve minimum beklenen süre arasındaki dengeyi bulmayı amaçlamıştır. ${ }^{12}$ Kholil ve diğerleri, 2018'de CPM metodunu zaman verimliliği için bir villa projesinin çizelgelemesinde kullanmışlardır. ${ }^{13}$ Konior ve Szóstak, 2020'de bir otel tesisi projesinde S-eğrilerini kullanarak planlanan işlerin planlanan maliyetlerini, gerçekleştirilen işlerin fiili maliyetleriyle karşılaştırmış ve inşaat projesinin seyrini analiz etmişlerdir. ${ }^{14}$

12 Wallace Agyae, "Project Planning And Scheduling Using PERT and CPM Techniques With Linear Programming: Case Study," International Journal of Scientific \& Technology Research 4 (2015), 222-227.

13 Muhammed Kholil, Bonitasari Nurul Alfa ve Madjumsyah Hariadi, "Scheduling of House Development Projects with CPM and PERT Method for Time Efficiency (Case Study: House Type 36)," Earth and Environmental Science 140 (2018), 1-2.

14 Jaroslaw Konior ve Mariusz Szostak, "The S-Curve as a Tool for Planning and Controlling of Construction Process-Case Study," Applied Sciences 10 (2020), 5-9. 


\section{CPM (Kritik Yol Metodu)}

CPM, planlamada kullanılan çizelgeleme esasına dayanan bir ağ metodudur. Çizelgeleme, proje iş kalemlerinin diğer bir ifadeyle faaliyetlerinin zamanlaması ve sıralaması olarak tanımlanabilir. ${ }^{15}$ Çizelgeleme yapılırken genel bir planlama yöntemi olan ağ analizi kullanılmaktadır. İnşaat planlamasında en yaygın kullanılan çizelgeleme ve ağ analizi yöntemlerinden biri CPM'dir. ${ }^{16}$ CPM'de proje toplam süresini verecek kritik yol olarak da isimlendirilen en uzun yol hesaplanmaktadır. Bu en uzun yol, projenin bitirilebilmesi için gerekli olan projenin minimum süresini vermektedir. ${ }^{17}$

1950’lerin sonlarında piyasaya sürülmesinden bu yana, Kritik Yol Metodu (CPM), inşaat projelerini planlamak ve kontrol etmek için yararlı bir araç olduğunu kanıtlamıştır. CPM, proje yöneticilerinin faaliyetlerin başlayabildiği ve bitirebildiği erken ve geç zamanları değerlendirmesini, aktivitelerin bolluk hesaplamasını, kritik faaliyetleri tanımlamasını ve süre ve mantıksal ilişkilerdeki değişikliklerin toplam proje süresi üzerindeki etkisini değerlendirmesini sağlamaktadır.

CPM'in bu faydaları ve bilgisayar programlama yazılımların gelişmesi ile CPM'in kullanımı son otuz yılda önemli ölçüde artmıştır. ${ }^{18}$ İnşaat projelerinde CPM çok önemlidir, çünkü yüklenicinin ne zaman ve ne kadar kaynağa ihtiyaç olduğunu, satıcıların malzemeleri ne zaman teslim edeceğini belirlemesini ve taşeronların işlerini ne zaman gerçekleştirebileceklerini planlamalarını sağlamaktadır. ${ }^{19}$

Bir proje başladığında, program, günlük faaliyetlerin başarılı koordinasyonu için gerekli hâle gelmekte ve ilerlemeyi ölçmek için bir temel olarak hareket etmektedir. Doğru saha olayları kaydedildiğinde ve programa girildiğinde, CPM analizi proje yöneticilerine gelecekte oluşabilecek sorunları tahmin etmede yardımcı olabilmektedir. ${ }^{20}$

\section{CPM Adımları}

İnşaat projelerinde CPM; bütün inşaat iş kalemlerinin süre ve birbirileri arasındaki öncelik sıralamaları göz önünde bulundurularak bir ağ şebekesi üzerinde çizelgelendiği, ileri ve geri matematiksel hesaplamalar yardımıyla iş kalemlerinin başlangıç ve bitiş zamanlarının hesaplandığı, proje süresini ve sonraki işleri geciktirmeden bir işin

15 Saleh Mubarak, Construction project scheduling and control (New York: John Wiley \& Sons, 2010), 43-81. 16 Mubarak, Construction Project Scheduling and Control, 43-81.

17 Harold Kerzner, Project Management: A Sysyems Approach to Planning, Scheduling, and Controlling (New York: John Wiley \& Sons, 2009), 493-555.

18 Mathew J. Liberatore, Bruce Pollack-Johnson ve Colleen A. Smith "Project Management In Construction: Software Use And Research Directions, ” Journal Of Construction Engineering And Management 127 (2001), 101-107.

19 Vishal Ahuja ve V. Thiruvengadam "Project Scheduling And Monitoring: Current Research Status," Construction Innovation 4 (2004), 19-31.

20 Frederick E. Gould, Managing The Construction Process:Estimating, Scheduling, and Project Control (New Jersey: Pearson Education, 2013), 170-171. 
geciktirilebileceği sürelerin (bolluk) belirlendiği, proje toplam süresini ve proje toplam süresini veren kritik yolun bulunduğu bir ağ planlama metodudur. ${ }^{21} \mathrm{CPM}$ ile proje süresinin hesaplanabilmesi için inşaat iş kalemlerinin iş sırası ve sürelerinin bilinmesi gereklidir. Proje süresini veren kritik yol üzerindeki iş kalemlerinin bolluğu sıfırdır.

CPM tekniğinde sırasıyla şu adımlar gerçekleştirilir:

İş kalemlerinin iş sıraları dikkate alınarak ok ve veya kutu tipi şebeke ağ planı çizilir. (Bu çalışmada ok tipi diyagram kullanılacaktır.)

İş kalemlerinin, diğer bir ifadeyle faaliyetlerin süreleri göz önünde bulundurularak ağ planında ileri ve geri matematiksel işlemler yapılarak; iş kalemlerinin en erken başlama (ES), en erken bitiş (EF), en geç başlama (LS) ve en geç bitiş (LS) zamanları hesaplanır.

İş kalemlerinin toplam bollukları hesaplanır.

Şebekede bollukları sıfır olan faaliyetlerin oluşturduğu kritik yol bulunarak toplam süre hesaplanır.

\section{Ok Tipi Şebeke Diyagramının Çizilmesi}

Şebeke ağ diyagramı çizilirken ilk olarak iş kalemlerinin süre ve iş sırası tespit edilmektedir. İş kalemlerinin sırası belirlenirken bir faaliyetin başlayabilmesi için önce iş kalemleri belirlenmelidir. İş kalemleri arasındaki bu ilişki öncül ve ardıl faaliyetlerin belirlenmesi olarak ifade edilebilir.

Tüm iş kalemleri ok tipi şebeke ağ planlamasında oklarla gösterilmektedir. $\mathrm{Bu}$ oklar bir düğüm noktasında başlayıp diğer düğüm noktasında bitmektedir. İlk başlayan iş kalemleri bir düğüm noktasından çıkarak soldan sağa doğru ağ planlaması çizelgelenmeye başlanmaktadır. Öncül sıralamalar dikkate alınarak her iş kaleminin ardından bir düğüm noktası koyularak yeni bir iş kalemi faaliyeti çizilmektedir. Bir düğüm noktasından birden fazla iş kalemi çıkabileceği gibi bir düğüm noktasına birden fazla iş kalemi de bağlanabilir. Ancak aynı düğüm noktasından çıkan birden fazla iş kalemi aynı dügüm noktasında birleşemez. Diğer bir ifadeyle farklı iş kalemlerinin hem başlangıç hem de bitiş dügüm noktaları aynı olamaz. Aynı düğüm noktasından çıkan çok sayıda iş kalemi faaliyeti kendilerinden sonra gelen iş kaleminin öncülü ise ağ planlamada çizim için kukla faaliyet kullanılmaktadır. Ardılı olmayan, kendisinden sonra yapılacak faaliyet olmayan iş kalemleri son bir bitiş düğüm noktasından toplanmaktadır.

21 Mohammed Lemar Zalmai, Cemil Akcay ve Ekrem Manisalı, "Time-Cost Optimization Using Harmony Search Algorithm In Construction Projects," Revista De La Construction 18 (2019), 226-237. 


\section{İş Kalemlerinin Başlangıç ve Bitiş Zamanlarının Hesaplanması}

İş kalemlerinin kendilerinden sonra gelecek faaliyetlerin başlama sürelerine etkileri göz önünde bulundurularak ES, EF, LS ve LF olmak üzere dört tane başlangıç ve bitiş zamanı hesaplanmaktadır. A ğ diyagramları çizildikten sonra ileri ve geri matematiksel işlemler yapılarak söz konusu başlangıç ve bitiş zamanları hesaplanmaktadır. Hesaplamada aşağıda verilen hesaplama adımları takip edilmektedir. ${ }^{22}$

1. Şebeke diyagramı çizildikten sonra ilk olarak ileri doğru matematiksel hesaplar yapılır. İleri doğru matematiksel hesaplamalar ile ES ve EF zamanları bulunur. İlk iş kaleminden son iş kalemine doğru öncül ve ardıl ilişkiler vasıtasıyla hesaplamalar yapılmaktadır. Bir iş kaleminin başlayabilmesi için kendisinden önceki faaliyetlerin başlayıp bitmiş olması gerekmektedir.

2. Sonraki iş kaleminin ES ve EF hesaplanırken kendisinden önceki faaliyetlerin en yüksek EF'i alınır ve buna iş kaleminin ES'ini oluşturur. ES'e faaliyetin süresi eklenerek EF bulunur.

3. Tüm iş kalemlerinin ES ve EF süreleri hesaplandıktan sonra ileri hesaplama tamamlanmış olur.

4. Geriye doğru matematiksel hesaplamalar ile iş kalemlerinin LS ve LF'leri bulunmaktadir.

5. Son düğüm noktasına bağlanan iş kalemlerinin en büyük EF değerine sahip olanı kritik faaliyettir. Ve bu iş kaleminin bitiş süresi proje süresini vermektedir. Bu doğrultuda son düğ̈̈m noktasına bağlanan iş kalemlerinin LF'si son düğüm noktasına bağlanan iş kalemlerinin en büyük EF’idir.

6. İş kalemlerinin LF zamanından iş kalemlerinin yapılma süreleri çıkartılarak LS hesaplanır.

\section{Faaliyetlerin Bolluklarının Hesaplanması}

Şebeke planlamada iki çeşit bolluk vardır. Bunlardan ilki toplam bolluktur (Total Float). Toplam bolluk, proje toplam süresini değiştirmeden bir iş kaleminin geciktirilebileceği azami süredir. İkincisi serbest bolluktur (Free Float). Serbest bolluk iş kaleminin kendisinden sonra gelen faaliyetin en erken başlama zamanını etkilemeden geciktirilebileceği süredir. Bu çalışmada toplam bolluk kullanılmıştır.

TB $($ Toplam Bolluk $)=$ LSi - ESi $($ i. faaliyetin en geç başlama zamanı - i. faaliyetin en erken başlama zaman1) ya da TB (Toplam Bolluk) = LFi - EFi (i. faaliyetin en geç bitiş zamanı - i. faaliyetin en erken bitiş zamanı). ${ }^{23}$

22 Yusuf Sait Türkkan, Proje Yönetiminde Planlama ve Kontrol Teknikleri (İstanbul: Doğu Kütüphanesi, 2015), 96-99.

23 Türkkan, Proje Yönetiminde Planlama ve Kontrol Teknikleri, 96-99. 


\section{Proje Süresinin Hesaplanması}

CPM şebeke planlamasında ileri ve geri matematiksel hesaplarla zamanların bulunmasından sonra iş kalemlerinin toplam bollukları hesaplanmaktadır. Toplam bolluğu sıfır olan iş kalemi faaliyetleri kritik faaliyetler olup bu iş kalemi faaliyetlerinin oluşturduğu çizelge de kritik yoldur. Kritik yol şebekede ayırt edilebilsin diye farklı çizilmektedir. Şebekede birden fazlada kritik yol olabilir. Kritik yol toplam proje tamamlanma süresini verir. Kritik yoldaki iş kalemi faaliyetlerinin sürelerinin değişimi doğrudan proje süresini etkilemektedir. Diğer bir ifadeyle kritik yol üzerindeki iş kalemlerinin tamamlanma sürelerindeki en küçük bir gecikme proje süresini uzatmaktadır.

\section{"S” Eğrilerine Dayalı Bütçeleme Tekniği}

"S" eğrileri, inşaat projelerinde projenin toplam ve zamana bağl1 maliyet değişimleri ve projede kullanılan kaynakların zamana bağlı değişimlerinin kümülatif olarak gösterildiği fonksiyonel proje kontrol araçlarıdır. ${ }^{24} \mathrm{~S}$-eğrileri proje gerçekleştirme aşaması için süreye bağlı maliyet dağılımını tahmin etmek için kullanılan bir metottur. $\mathrm{Bu}$ yöntem, inşaat projelerinin tüm aşamalarında, özellikle proje hakkında ayrıntılı bilgilerin az olduğu en erken aşamada nakit akışı tahmini için kullanılabilir. ${ }^{25}$

Tipik bir 'S' eğrisi incelendiğinde (G. 10) ${ }^{26}$ zamana bağl1 kümülatif proje maliyet artışının grafiğinin S şeklinde olduğu görülmektedir. Grafik incelendiğinde başlangıç döneminde toplam proje süresinin 1/3'üne denk gelen kısımda proje maliyetinin \%25'inin gerçekleştiği fark edilmektedir. İkinci kısımda ise işler ilerledikçe süreye bağlı proje maliyetlerinde artış olduğu görülmektedir. Yaklaşık proje bütçesinin yarısının harcandığı bu dönem proje sürenin 1/3'lük kısmını oluşturmaktadır. Proje sürecinin son kısmını oluşturan sürede ise işlerin sonlanma aşamasına doğru harcama oranları düşüş göstermekte ve bu durum proje bütçesinin $1 / 4$ 'üne tekabül etmektedir. Özetle proje süresi üçe bölündüğunde proje bütçesinin yarısı ikinci zaman diliminde harcanırken başlangıç ve bitiş zamanlarında kalan bütçenin \%25'inin kullanıldığ 1 söylenebilir.

24 Türkkan, Proje Yönetiminde Planlama ve Kontrol Teknikleri, 137-144.

25 Nives Ostojić-Škomrlj ve Mladen Radujković, “ S-Curve Modelling in Early Phases Of Construction Projects," Gradevinar 64 (2012), 647-654.

26 Türkkan, Proje Yönetiminde Planlama ve Kontrol Teknikleri, 138-139 


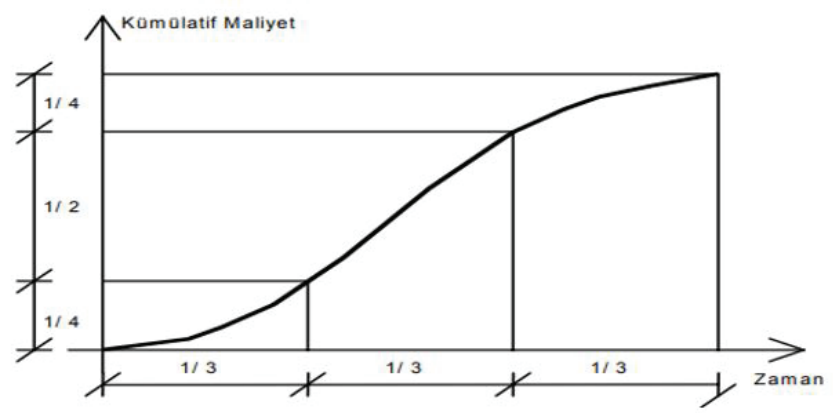

G. 10 : Tipik "S” Eğrisi (Yusuf Sait Türkkan, 2015)

"S" eğrileri inşaat projelerinde maliyet kontrolünün yanı sıra proje gider ve bütçedeki nakit akışların oluşturulmasında da kullanılmaktadır. Malzeme, işçilik, ekipman ve taşeron maliyetleri gibi birden fazla proje bütçe gider kalemi aynı grafik üzerinde gösterilmektedir (G. 11). ${ }^{27}$ Ayrıca süre ve maliyet sapmaları da analiz edilerek "S" eğrileri yardımıyla kontrol edilebilmektedir (G. 12). ${ }^{28}$

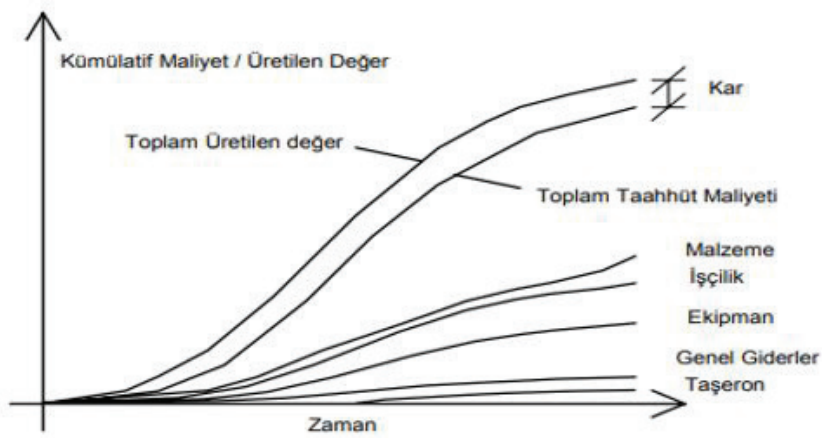

G. 11: Alt maliyetlere ayrılmış maliyet eğrisi (İlker Özdemir ve Arzu Bodur, 2000)

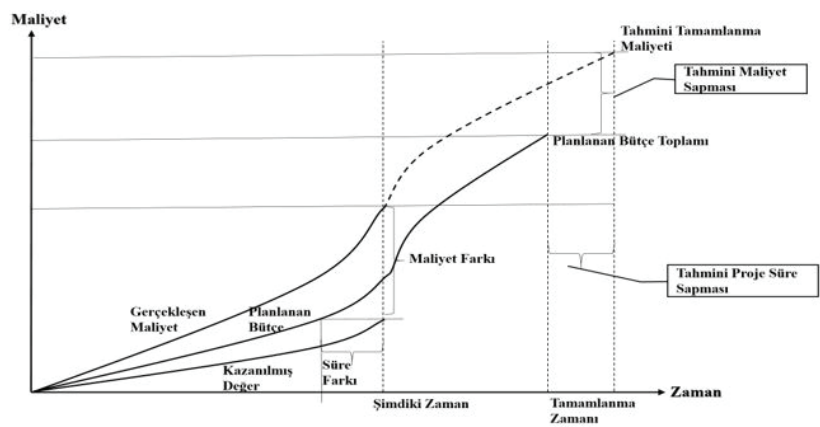

G. 12: Maliyet analizi amacıyla taahhüt maliyet eğrilerinin kullanılması (APM Guidelines, 2008)

27 İlker Özdemir ve Arzu Bodur, “Türkiye'de Yapı Projelerinin Nakit Akış Sorunlarının Yazılım Desteğiyle İzlenmesi ve Çözümlenmesi,” 2. Yapı İşletmesi Kongresinde Sunulan bildiri, İzmir, 15-17 Haziran 2020.

28 Association for Project Management, Earned Value Management APM Guidelines (Buckinghamshire: APM, 2008), 27. 


\section{Bulgular}

Tarihi Yarımada'da gerçekleştirilen inşaat işlerinde arkeolojik kazının süre ve maliyete etkileri henüz inşaatına başlanmamış planlama aşamasındaki bir inşaat işi üzerinden incelenmiştir. Söz konusu inşaatın farklı bir alanda arkeolojik kazı yapılmadan gerçekleştirilmesi ile bu alanda gerçekleştirilmesi durumunda iş kalemleri, inşaat süresi ve inşaat maliyetleri açısından oluşacak farklılıklar tespit edilmiştir. $\mathrm{Bu}$ doğrultuda örnek olarak İstanbul Üniversitesi Ana kampüsünde gerçekleştirilecek olan yemekhane binası projesi ele alınmıştır.

\subsection{Proje Bilgileri}

Projenin yapılacağı alan G.13'te, vaziyet planı ise G.14'de görülmektedir. Mevcut yer üstündeki yıkılan yemekhane binasının tamamen yer altında yapılması planlanmıştır.

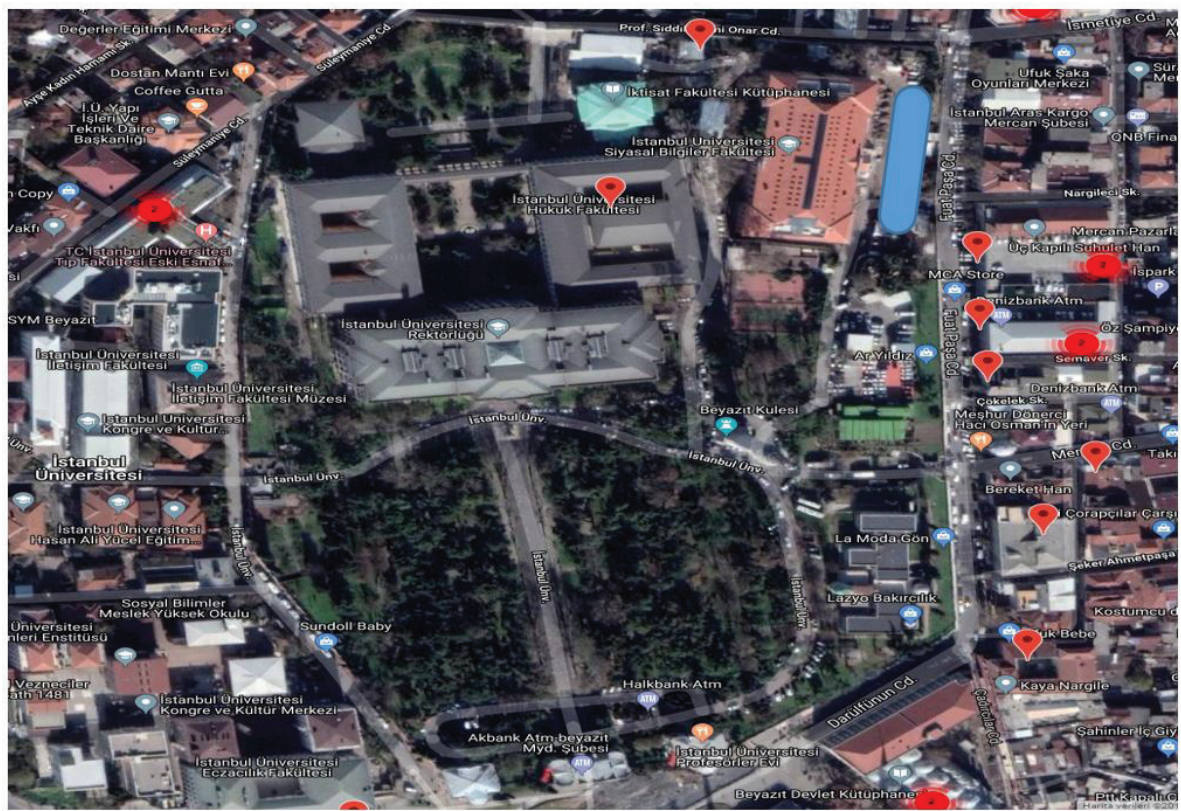

G. 13: Proje Uygulama Alanı (Proje Uygulama Raporu, ZH Kılıç Mimarlık, 2019) 




G. 14: Yemekhane Binası Vaziyet Planı (Proje Uygulama Raporu, ZH Kılıç Mimarlık, 2019)

Bina oturum alan $2280 \mathrm{~m}^{2}$ olup toplam kapalı alanı $5662 \mathrm{~m}^{2}$ 'dir. Proje iki bodrum kattan oluşmaktadır. Projenin kesiti G. 15'te görülmektedir. Projeye ait görseller ise G. 16'da verilmiştir.

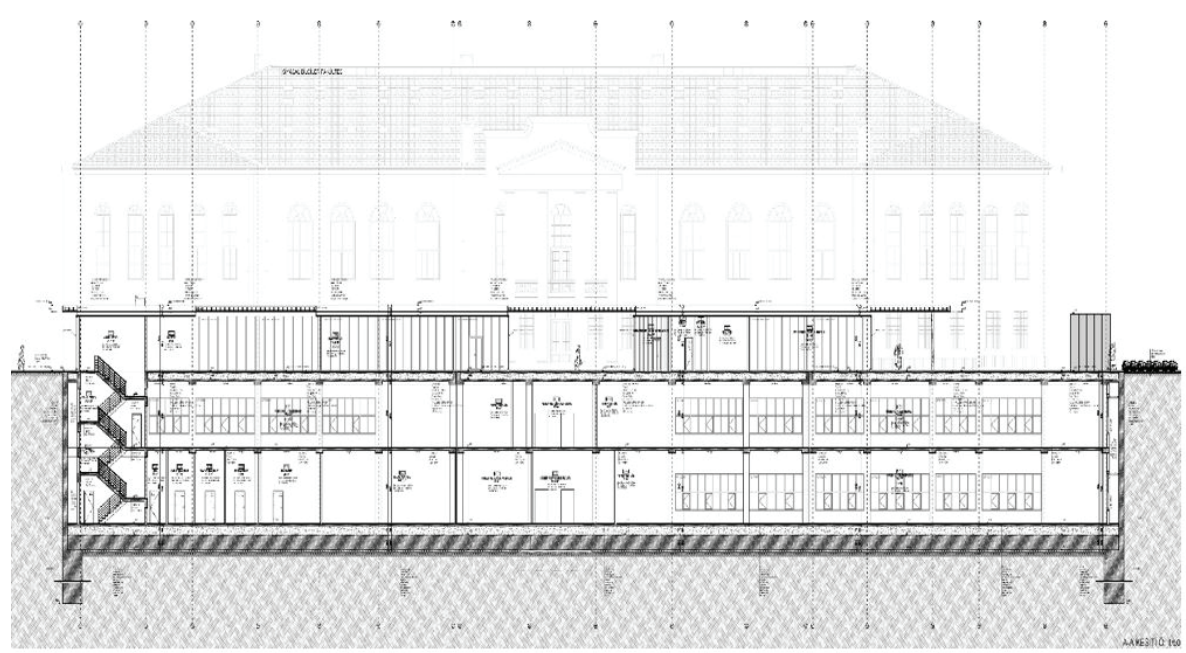

G. 15: Projeden Bir Kesit (Proje Uygulama Raporu, ZH K1lıç Mimarlık, 2019) 


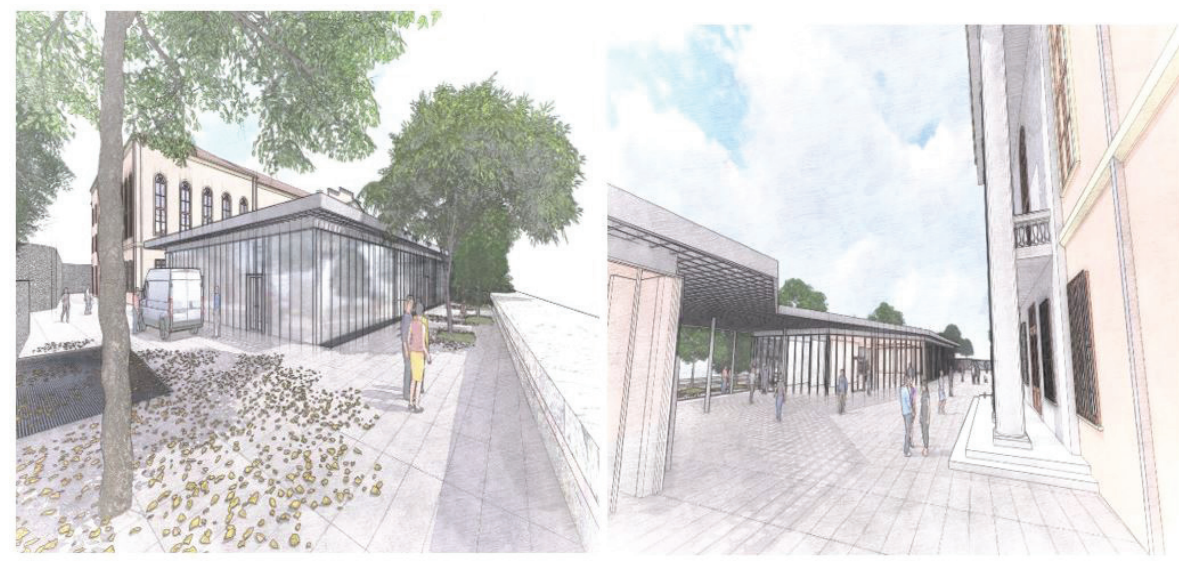

G. 16: Proje Görselleri (Proje Uygulama Raporu, ZH K1lıç Mimarlık, 2019)

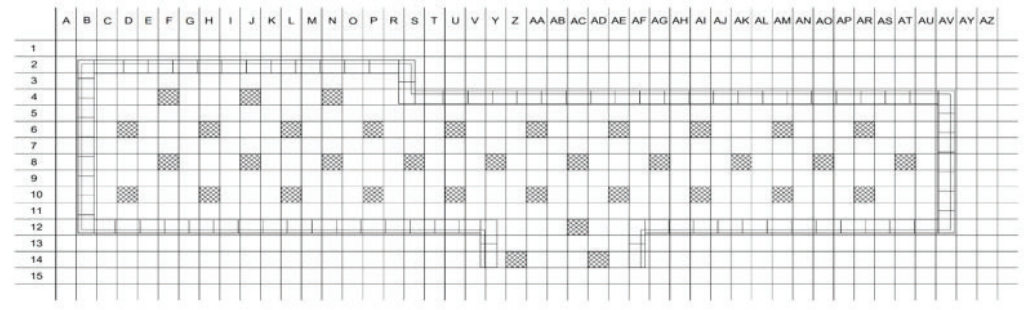

ARKEOLOJIK ARAȘTIRMA KAZISI PLANKARE APLIKASYONU

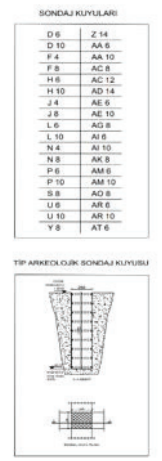

G. 17: Arkeolojik Araştırma Kazısı Aplikasyon Planı (Cemil Akçay, 2021)

\section{Kuyu Temel İksa Arkeolojik Kazıları}

İksa sistemi olarak fore kazık vb. yöntemlerin yerine tarihî çevredeki inşaat işlerinde genellikle kuyu temel yöntemi kullanılmaktadır. Kuyu temel imalatında da yapılan kazılar elle arkeolojik kazıdır. G. 18'de kuyu temel iksa yerleşim planı görülmektedir. G. 19'da ise kuyu temel ve istinat yapısı kesitleri yer almaktadır.

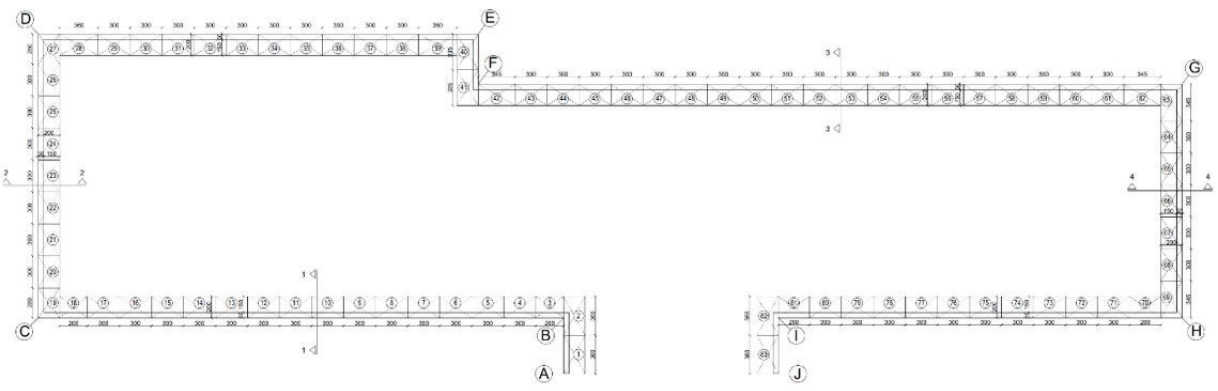

G. 18: Kuyu Temel İksa Yerleşim Planı (ZH K1lıç Mimarlık, 2021) 

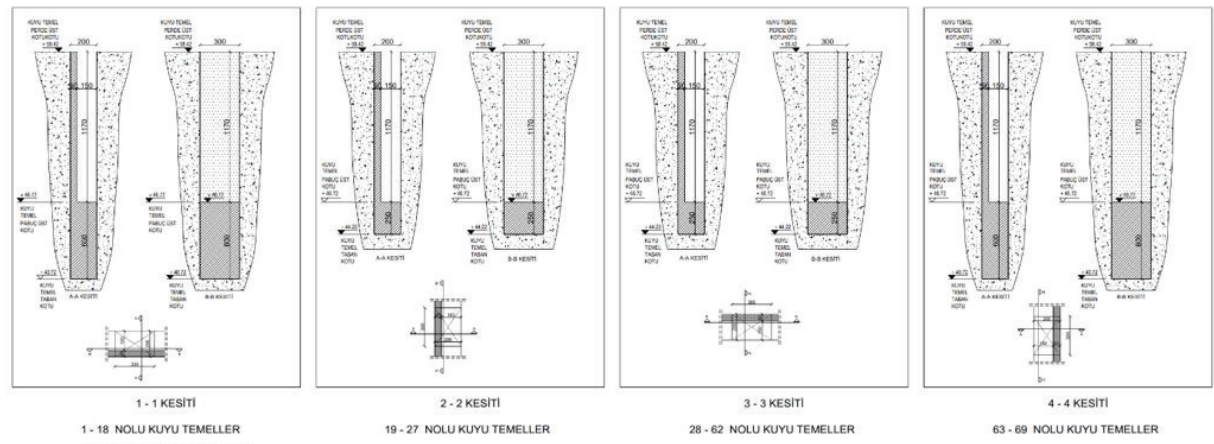

G. 19: Kuyu Temel ve İksa Sistemi Kesitleri (ZH Kılıç Mimarlık, 2021)

\section{Arkeolojik Kazı ve Kuyu Temel Süre ve Maliyet Analizi}

İncelenen projede; arkeolojik araştırma kazısı, kuyu temel arkeolojik kazısı, kuyu temel iksa imalatları ile hafriyatın uzaklaştırılarak temel atma seviyesine gelinceye kadarki inşaat imalatları maliyetleri tablo hâlinde verilmiştir.

Tablo 1: Kuyu Temel ve İksa Sistemleri Maliyet Özet Tablosu (Cemil Akçay, 2021)

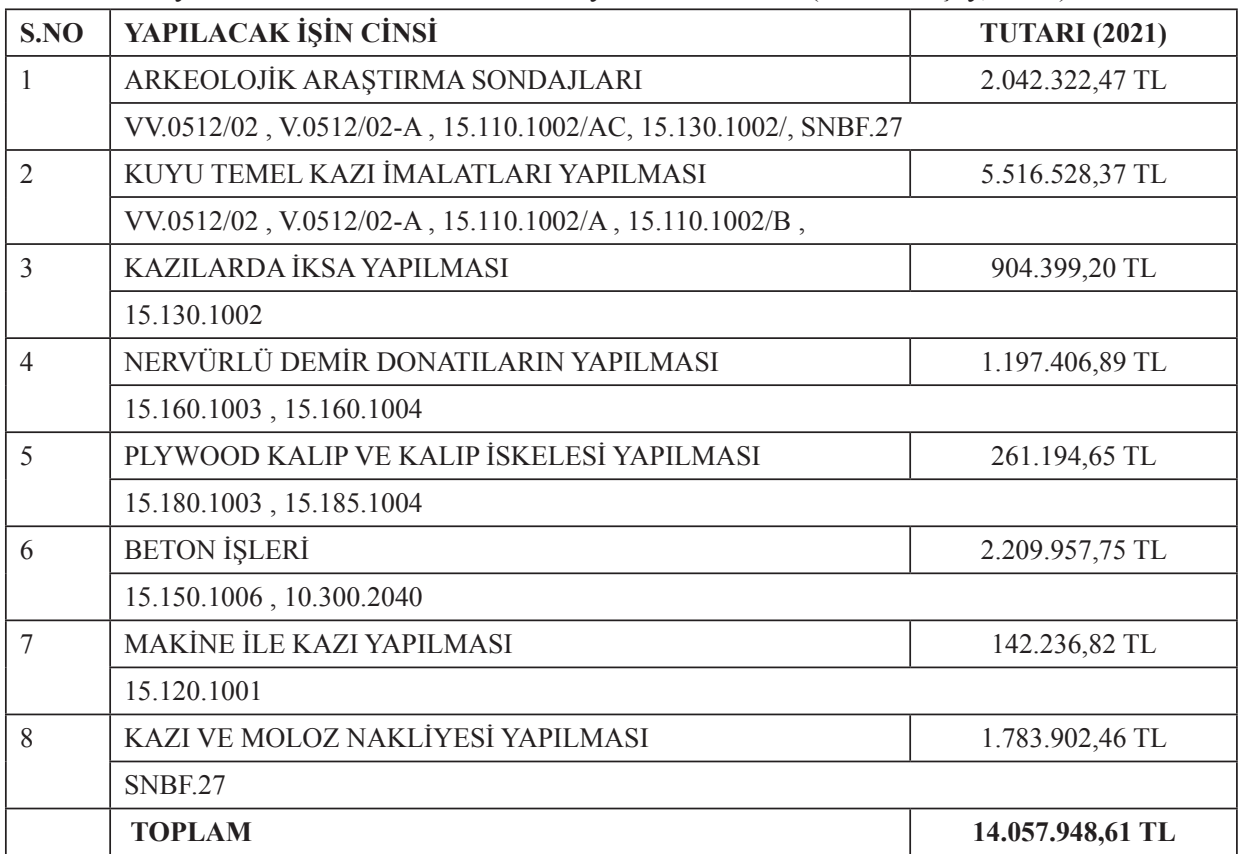

Arkeolojik kazı ile yapılan imalatların yapım süresi bir diğer ifadeyle proje toplam süresi CPM metodu ile hesaplanarak oluşturulan ağ diyagramı G. 20'de verilmiştir. Yapılan hesap sonucu proje süresi 480 gün olarak hesaplanmıştır. 


$\begin{array}{llc}\text { ADTIVITE KODU } & \text { AKTIVITE ADI } & \text { HÖFÜ } \\ \text { A } & \text { ARKEOLOJIK ARAŞTIRMA SONDAJLARI } & - \\ \text { B } & \text { KUYU TEMEL KAZI İMALATLARI YAPILMASI } & \mathrm{A} \\ \text { C } & \text { KAZILARDA IKSA YAPILMASI } & \mathrm{A} \\ \text { D } & \text { NERVÜRLÜ DEMIR DONATILARIN YAPILMASI } & \text { B-SS+7, C-SS+7 } \\ \text { E } & \text { PLYWOOD KALIP VE KALIP İSKELESI YAPILMASI } & \text { D-SS+10 } \\ \text { F } & \text { BETON İŞERI } & \text { E-SS+7 } \\ \text { G } & \text { MAKINE İLE KAZI YAPILMASI } & \mathrm{F} \\ \text { H } & \text { KAZI VE MOLOZ NAKLIYESI YAPILMASI } & \text { A-SS+7 }\end{array}$

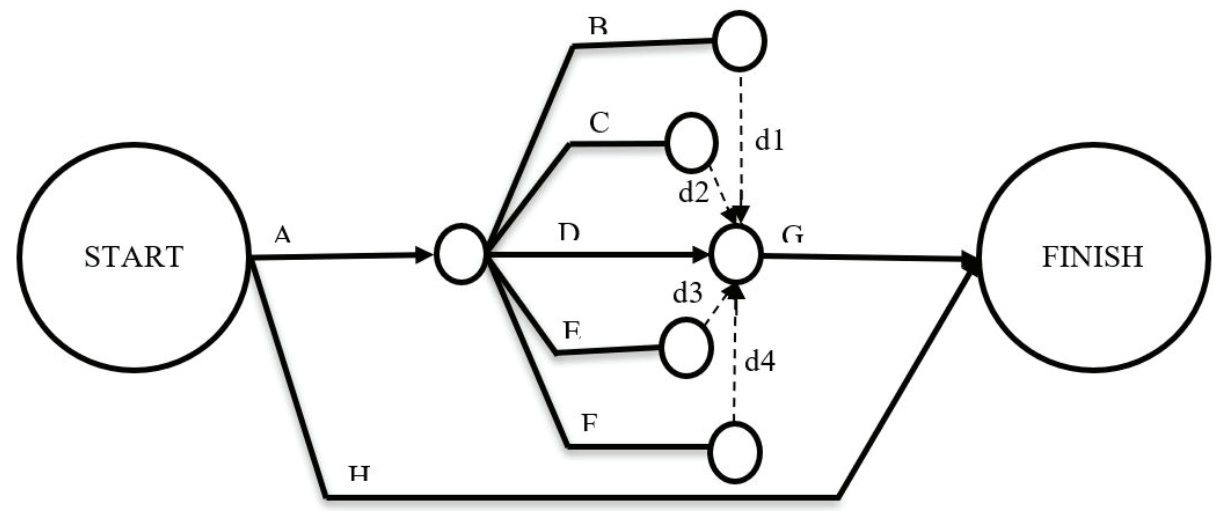

G. 20: Kuyu Temel ve İksa Sistemleri İnşaat CPM İş Programı (Cemil Akçay, 2021)

\section{Alternatif İnşaat Metodu ile Kazı ve İksa Yapılması}

Söz konusu inşaat işinin Tarihi Yarımada dışında başka bir alanda yapılması durumunda kazının tamamı makinalı olarak yapılacak olup iksa sistemi olarak da fore kazık vb sistem kullanılacaktır. Arkeolojik kazı, kuyu temel gibi imalatların süre ve maliyete etkisini ölçebilmek için uygulanan alternatif yöntemlerle işlerin yürütülmesi durumundaki hesaplamaların yapılarak verilerin elde edilmesi gerekmektedir. $\mathrm{Bu}$ çalışmada alternatif iksa sistemi olarak fore kazık, alternatif kazı yöntemi olarak ise temel alt kotuna kadar makinalı kazı yapılacağı kabulüyle hesaplamalar yapılmıştır. G. 21'de fore kazık yerleşim planı ile kazık detayları görülmektedir. 




G. 21: Fore Kazık İksa Yerleşim ve Detay Planı (İ.Ü. Yapı İşleri tarafından uygulanan benzer bir projedeki detaydan faydalanılarak hazırlanmıştır. Detay planı Oğuz Üner, yerleşim planı Cemil Akçay, 2021)

Temel atma seviyesine kadarki inşaat imalatlarının fore kazık ve makinalı kazı ile yapılması durumundaki maliyet hesabı tablo olarak verilmiştir.

Tablo 2: Fore Kazık ve Makinalı Kazı Maliyet Özet Tablosu (Cemil Akçay, 2021)

\begin{tabular}{|c|c|c|}
\hline S.NO & YAPILACAK İŞİN CINSİ & TUTARI (2021) \\
\hline \multirow[t]{2}{*}{1} & FORE KAZIK DELGILERININN YAPILMASI & $3.953 .194,56 \mathrm{TL}$ \\
\hline & 15.140 .1010 & \\
\hline \multirow[t]{2}{*}{2} & NERVÜRLÜ DEMİR DONATILARIN YAPILMASI & 2.743.208,06 TL \\
\hline & $15.160 .1003,15.160 .1004$ & \\
\hline \multirow[t]{2}{*}{3} & PLYWOOD KALIP VE KALIP İSKELESİ YAPILMASI & $55.378,42 \mathrm{TL}$ \\
\hline & $15.180 .1003,15.185 .1004$ & \\
\hline \multirow[t]{2}{*}{4} & BETON İŞLERİ & $131.133,24 \mathrm{TL}$ \\
\hline & 15.150 .1006 & \\
\hline \multirow[t]{2}{*}{5} & MAKİNE İLE KAZI YAPILMASI & $168.117,55 \mathrm{TL}$ \\
\hline & 15.120 .1001 & \\
\hline \multirow[t]{3}{*}{6} & KAZI VE MOLOZ NAKLIYESİ YAPILMASI & $1.858 .539,52 \mathrm{TL}$ \\
\hline & SNBF.27 & \\
\hline & TOPLAM & 8.909.571,35 TL \\
\hline
\end{tabular}

Fore kazık sistemi ile iksa yapılması ve makinalı kazı ile hafriyatın alınarak temel atma seviyesine kadar inşaatın yapılması işinin proje toplam süresi CPM metodu ile hesaplanarak ağ diyagramı G. 22'de verilmiştir. Yapılan hesap sonucu proje süresi 225 gün olarak hesaplanmıştır. 


\begin{tabular}{|c|c|c|}
\hline $\begin{array}{l}\text { ADTIVITE } \\
\text { KODU }\end{array}$ & AKTIVITE ADI & HÖFÜ \\
\hline A & FORE KAZIK DELGILERINIIN YAPILMASI & - \\
\hline B & FORE KAZIK NERVÜRLÜ DEMIR DONATILARIN MONTAJI & - \\
\hline $\mathrm{C}$ & FORE KAZIK BETON İŞLERİ & $\mathrm{B}-\mathrm{SS}+7$ \\
\hline $\mathrm{D}$ & BAŞLIK KİRIŞINININ DEMİR MONTAJI & $\mathrm{A}, \mathrm{B}, \mathrm{C}$ \\
\hline E & BAȘLIK KİRIŞİ PLYWOOD KALIP VE KALIP İSKELESİ YAPILMASI & $\mathrm{D}-\mathrm{SS}+7$ \\
\hline $\mathrm{F}$ & BAŞLIK KİRIŞİ BETON İŞLERİ & $\mathrm{D}, \mathrm{E}$ \\
\hline G & MAKINE İLE KAZI YAPILMASI & $\mathrm{F}$ \\
\hline $\mathrm{H}$ & KAZI VE MOLOZ NAKLIYYESI YAPILMASI & G-SS \\
\hline I & GÖĞÜSLEME KİRIŞİ DEMİR BAĞLAMA İŞLERİ & G-SS+10 \\
\hline $\mathrm{J}$ & $\begin{array}{l}\text { GÖĞÜSLEME KİRIŞİ PLYWOOD KALIP VE KALIP İSKELESİ } \\
\text { YAPILMASI }\end{array}$ & $\mathrm{I}-\mathrm{SS}+4$ \\
\hline K & GÖĞÜSLEME KİRIŞI BETON İŞLERİ & $\mathrm{I}, \mathrm{J}$ \\
\hline
\end{tabular}



G. 22: Fore Kazık ve Makinalı Kazı İnşaat CPM İş Programı (Cemil Akçay, 2021)

\section{"S"Eğrileri}

İki alternatif inşaat metodu için "S" eğrileri çizilmiştir. G. 23'te süre ve maliyet, kümülatif olarak hesaplanarak verilmiştir. Eğriler incelendiğinde arkeolojik kazı ve kuyu temel ile inşaatın yapılması durumunda inşaat süresi 16 ay ve toplam maliyet 14.057.948, 61 TL (2021 y1lı fiyatları ile) olmaktadır. Fore kazık iksa sistemi ile hafriyatın tamamının makinalı olarak alınması durumunda ise inşaat süresi 7,5 ay sürmekte ve toplam maliyet 8.909.571, 35 TL (2021) tutmaktadır. 
KUYU TEMEL VE FORE KAZIKL TEMEL PROJELERIN S EGERILERI



G. 23: "S"Eğrileri (Cemil Akçay, 2021)

\section{Alternatif Yöntemlerin Avantajları ve Dezavantajları}

Süre ve maliyet kriterlerinin yanı sıra kentsel ve tarihi sit alanlarında iksa sistemlerinde dikkate alınması gereken önemli hususlarda birisi de yer altında arkeolojik kalıntı bulunduran kültür katmanlarının zarar görme ihtimali ile çevrede bulunan özellikle korunması gerekli kültür varlığı olarak tescilli yapıların oluşacak titreşimlerden etkilenme olasılığıdır. Fore kazık yapımı sırasında, makinayla yer altında görmediğimiz bir ortamda zemin kazılarak iksa sisteminin alt yapısı oluşturulmaktadır. Delgi yöntemiyle yapılan bu kazı sırasında yer altında herhangi bir arkeolojik kalıntı veya herhangi bir altyapı varsa bunun zarar görmesi muhtemeldir. İnşaat öncesi jeoradar yöntemi ile yer altı haritalarının çıkarılması bu riskleri azaltmaktadır. İksa sisteminin kuyu temel yöntemiyle yapılması durumunda, kazı el aletleriyle gözle görülür bir şekilde yapıldığg için arkeolojik kültür kalıntılarının zarar görmeden ortaya çıkarılması mümkün olmaktadır. Yine iksa sistemleri yapımı sırasında ortaya çıkacak titreşimlerin yakın çevre yapılardaki etkilerinin de takip edilmesi önemlidir. Fore kazık imalatının yapımı sırasında oldukça yüksek frekanslı titreşimler oluşmaktadır. Bu titreşimlerin eski eser niteliğindeki yapılarda olumsuz etkileri dikkate alınmalıdır. Bu sebeple İksa yapım sırasındaki riskleri yönetmek için özellikle fore kazık imalatlarında oluşan deplasmanların ve çevre yapılardaki olası oturma ve deplasmanların uygun cihazlar yardımıyla yapılacak ölçümlerle gözlemlenmesi gerekmektedir. ${ }^{29}$ Kuyu temel imalatında oluşan titreşimler oldukça düşük seviyede kaldığı için komşu yapılara etkisi de oldukça sınırlıdır. Örneğimizdeki yapının batı yönünde komşusu olan Siyasal Bilgiler Fakültesi I. Derece tescilli eserdir ve fore kazık yöntemi seçilmesi durumunda oluşacak titreşimlerin yapıda hasar oluşturma riski mevcuttur. Doğu ve kuzey yönünde

29 Mustafa Dayığlu, "Derin Kazıların İncelenmesi ve Derin Kazı Uygulaması Üzerine Bir Örnek: Harbiye Kongre Merkezi Derin Temel Kazısı” (Yüksek Lisans Tezi, İstanbul Teknik Üniversitesi, 2010), 5; Şule Karadüz, "Derin Kazı Teknikleri ve Derin Kazı Destekleme Sistemlerine Bir Örnek: Atatürk Kültür Merkezi Kızılay Metro Hattı Projesi, Gar Bölümü” (Yüksek Lisans Tezi, Süleyman Demirel Üniversitesi, 2019 ), 1. 
ise korunması gerekli kültür varlığı olarak tescilli olan çevre istinat duvarları ve sıra dükkânlar ile komşudur. Çevre istinat duvarlarının temel ve payanda sistemi tam olarak bilinemediğinden yapılacak olan fore kazık sondajları sırasında söz konusu temel sistemleri zarar görebilecektir. Kuyu temel uygulamasında ise sondaj kuyuları kontrollü bir şekilde el ile açılacağı için bu risk ortadan kalkacaktır.

\section{Sonuç}

Tarihi Yarımada'da inşaat çalışması yapmak belirli kurallara bağlanmıştır. Kentsel ve tarihî sit alanlarında inşaat, Kültür Varlıklarını Koruma Bölge Kurulları tarafından onaylanan Koruma Amaçlı İmar Planları doğrultusunda yapılmaktadır. Bölgedeki yenileme alanlarındaki uygulama ise imar planlarının yanı sıra ilgili belediye tarafindan hazırlanan ve yine Koruma Bölge Kurullarınca onaylanan ada bazındaki avan projeleri doğrultusunda gerçekleştirilmektedir.

Bölgede yapılan inşaat çalışmalarına öncelikle İAM denetiminde arkeolojik araştırma sondajları açılarak başlanmaktadır. Söz konusu araştırma kazıları neticesinde taşınır veya taşınmaz kültür varlığına rastlanmadığı durumlarda inşaat işleri devam etmektedir. Taşınmaz kültür varlığına rastlanılması durumunda, söz konusu taşınmazların rölöveleri çıkarılmakta ve korunup korunmayacaklarına yine Kültür Varlıklarını Koruma Bölge Kurullarınca karar verilmektedir. Söz konusu kararlar doğrultusunda inşaat projelerinin yapılıp yapılmayacağı veya revize edilmesi durumu gündeme gelmektedir. Bu çalışmalardan dolayı bölgede inşaat işi yapmanın maliyeti artmakta ve inşaat süresi uzamaktadır. Bu sebeplerle de işverenler ve işi yapacak yüklenicilerin bu durumu göz önünde bulundurarak planlama yapmaları gerekmektedir.

Bu çalışmada arkeolojik kazı, kuyu temel gibi kentsel ve tarihi sit alanlarındaki inşaat işlerinde kullanılan metotların süre ve maliyete etkileri incelenmiştir. Bu doğrultuda büyük bölümü toprak altında kalan örnek bir proje ele alınmıştır. Projede temel seviyesine kadarki kazı ve iksa imalatları iki alternatifli olarak hesaplanmıştır. Birinci alternatifte arkeolojik araştırma kazısı, kuyu temel iksa sistemi kullanılmıştır. İkinci alternatifte ise inşaatın bu bölge dışında normal bir alanda yapılması durumunda uygulanacak fore kazık ve makinalı kazı imalatları tercih edilmiştir. Her iki alternatif için inşaat iş kalemleri, metraj ve maliyet çalışması çıkarılmıştır. İnşaat süre hesabı, şebeke ağ planlaması olan CPM yöntemi ile yapılmıştır. Çizilen "S" eğrileriyle de iki alternatifin kümülatif olarak süre ve maliyetleri karşılaştırılmıştır. Karşılaştırmalı maliyet ve süre grafikleri G. 24 ve G. 25 'te verilmiştir. 


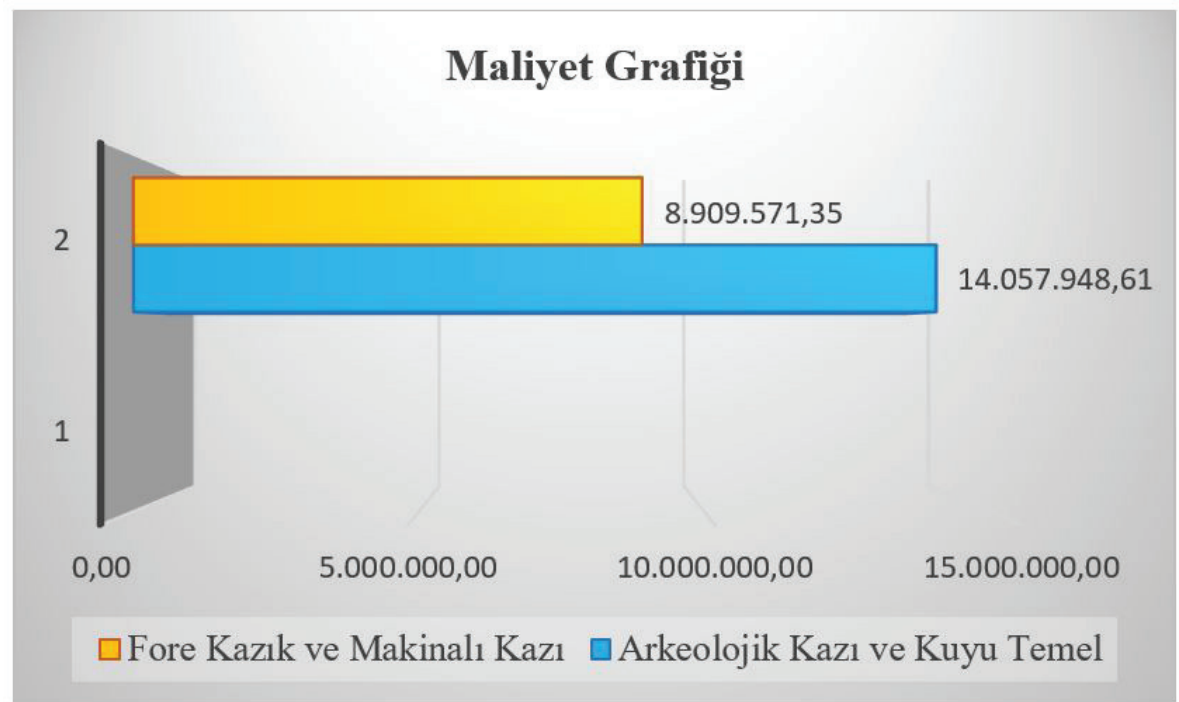

G. 24: Alternatif İnşaat Maliyet Grafiği (Cemil Akçay, 2021)

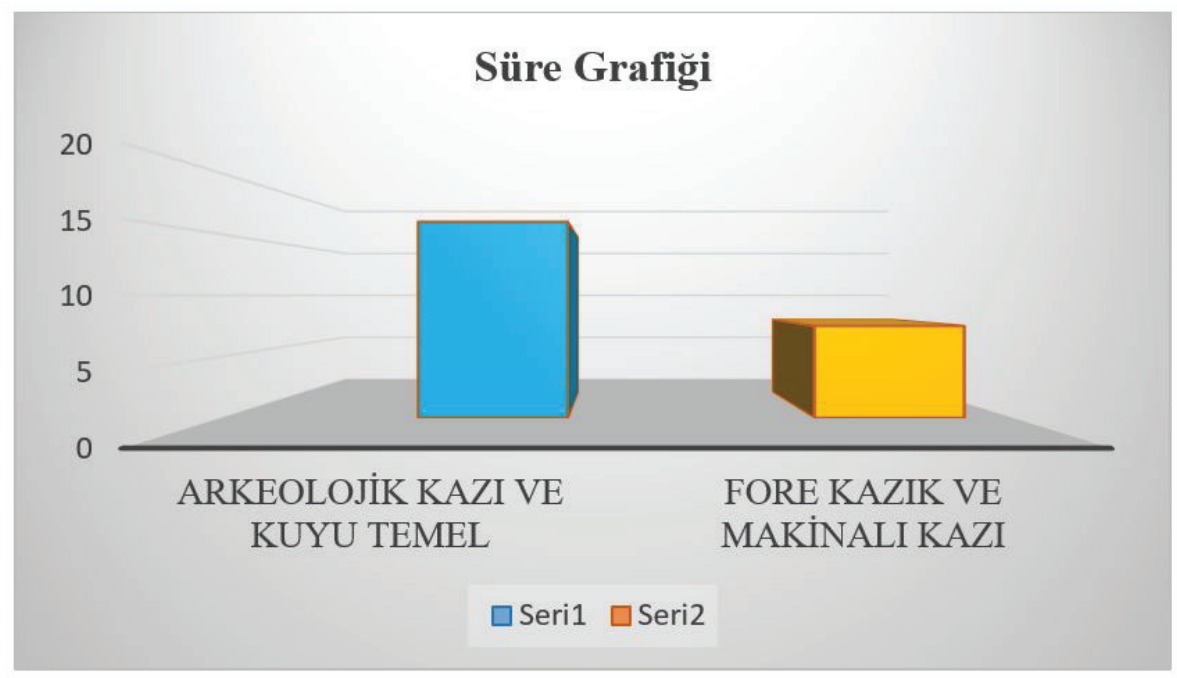

G. 25: Alternatif İnşaat Süre Grafiği (Cemil Akçay, 2021)

Grafikler incelendiğinde arkeolojik kazı ve kuyu temel imalat maliyet toplamının fore kazık ve makinalı kazıya göre $\% 58$, sürenin ise $\% 113$ daha fazla olduğu görülmektedir.

Tarihi Yarımada plan notları ve Kurul Kararları doğrultusunda araştırma kazıları İAM denetiminde arkeolojik kazı olarak yapılmaktadır. Süre ve maliyeti fazla çıkmasına rağmen çevrede bulunan tescilli yapıların titreşimden zarar görmemesi, istinat 
yapısının temeliyle olası arkeolojik bulguların korunabilmesi için de en güvenli yöntemin kuyu temel olacağ 1 değerlendirilmiştir.

Bu çalışmada elde edilen sonuçlar, Tarihi Yarımada'da yapılacak inşaatların süre ve maliyet planlamasında kullanılabilecektir. Bölgede farklı inşaatlar için yapılacak benzer çalışmalarla da bu alandaki veri havuzunun genişletilebileceği öngörülmektedir. Konuyla ilgili araştırmacılara örnek olabilecek bu çalışmada maliyetler, birim fiyatlar göz önünde bulundurularak hesaplanmıştır. Söz konusu fiyatlara \% 25 yüklenici kârı ve genel giderler dâhildir (yaklaşık \% 10 civarı kar $4+\% 15$ civarı genel gider). Sürenin uzamasından dolayı oluşacak sabit maliyetler ayrıca hesaba dâhil edilmemiştir.

\footnotetext{
Hakem Değerlendirmesi: Dış bağımsız.

Çıkar Çatışması: Yazar çıkar çatışması bildirmemiştir.

Finansal Destek: Yazar bu çalışma için finansal destek almadığını beyan etmiştir.

Peer-review: Externally peer-reviewed.

Conflict of Interest: The author has no conflict of interest to declare.

Grant Support: The author declared that this study has received no financial support.
}

\section{Kaynakça/References}

Ahuja, Vishal ve V. Thiruvengadam. "Project Scheduling And Monitoring: Current Research Status." Construction Innovation 4 (2004): 19-31.

Agyae, Wallace. "Project Planning and Scheduling Using PERT And CPM Techniques With Linear Programming: Case Study.” International Journal of Scientific \& Technology Rresearch 4 (2015): 222-227.

Association for Project Management, Earned Value Management APM Guidelines. Buckinghamshire: APM, 2008.

Başaran, Sait ve Ufuk Kocabaş. “Theodosius Limanı'ndan Yenikapı Batıklarına.” Colloquium Anatolicum Dergisi 13 (2008): 1-22.

Dayığlu, Mustafa. "Derin Kazıların İncelenmesi ve Derin Kazı Uygulaması Üzerine Bir Örnek: Harbiye Kongre Merkezi Derin Temel Kazısı.” Yüksek Lisans Tezi, İstanbul Teknik Üniversitesi, 2010.

Esin, Ufuk. İstanbul'un En Eski Buluntu Yerleri ve Kültürleri, Semavi Eyice Armağanı İstanbul Yazıları. İstanbul: Türkiye Turing ve Otomobil Kurumu, 1992.

Gould, Frederick E. Managing The Construction Process:Estimating, Scheduling, and Project Control, Fourth Edition. New Jersey: Pearson Education, 2013.

İstanbul Tarihi Yarımada Yönetim Planı. İstanbul: İBB ve T.C. Kültür ve Turizm Bakanlığı, 2018.

Kaplan, Onur. "5366 Sayılı Kanun Kapsamında Yenileme Alanlarında Gerçekleştirilen Kentsel Dönüşüm Süreci Üzerine Bir Deneme.” Hacettepe Hukuk Fakültesi Dergisi 7 (2014): 275-304.

Karadüz, Şule. "Derin Kazı Teknikleri ve Derin Kazı Destekleme Sistemlerine Bir Örnek: Atatürk Kültür Merkezi Kızılay Metro Hattı Projesi, Gar Bölümü.” Yüksek Lisans Tezi, Süleyman Demirel Üniversitesi, 2019. 
Karakuyu, Mehmet, Saadet Tuğçe Tezer ve Hatice Balık. "İstanbul'un Tarihsel Topoğrafyası ve Literatür Değerlendirmesi.” Türkiye Araştırmalar Literatür Dergisi 6 (2010): 33-60.

Kerzner, Harold. Project Management A Sysyems Approach to Planning, Scheduling, and Controlling. New York: John Wiley \& Sons, 2009.

Kholil, Muhammed, Bonitasari Nurul Alfa ve Madjumsyah Hariadi. "Scheduling of House Development Projects with CPM and PERT Method for Time Efficiency (Case Study: House Type 36)." Earth and Environmental Science 140 (2018): 1-2.

Kızıltan, Zeynep ve Mehmet Ali Polat. Yenikapı Kurtarma Kazıları: Neolotik Dönem Çalışmaları," Arkeoloji ve Sanat Dergisi 143 (2013): 1-40.

Kızıltan, Zeynep. "Marmaray-Metro Projeleri ve Yenikapı Arkeolojik Kurtarma Kazıları." Colloquium Anatolicum Dergisi 13 (2014): 11-44.

Konior, Jaroslaw ve Mariusz Szostak. "The S-Curve as a Tool for Planning and Controlling of Construction Process-Case Study." Applied Sciences "10 (2020): 5-9.

Liberatore, J. Mathew, Bruce Pollack-Johnson ve Colleen A. Smith. "Project Management In Construction: Software Use And Research Directions. ” Journal Of Construction Engineering And Management 127 (2001): 101-107.

Mubarak, Saleh. Construction Project Scheduling and Control. Florida: John Wiley \& Sons, 2010.

Özden, Örnek Elif. "Kentsel Sit Alanı Mutlak Korunuyor Anlamına Geliyor mu.” Gazi Üniversitesi Mühendislik Mimarlık Fakültesi Dergisi, 4 (2006): 651-660.

Özdemir, İlker ve Arzu Bodur. “Türkiye'de Yapı Projelerinin Nakit Akış Sorunlarının Yazılım Desteğiyle İzlenmesi ve Çözümlenmesi.” 2. Yapı İşletmesi Kongresinde Sunulan bildiri, İzmir, 15-17 Haziran 2020.

Rukanc1, Fatih ve Hakan Anameriç. “Arşiv Belgeleri ile II. Abdülhamid Dönemi Müzecilik Faaliyetleri." Tarih Araştırmaları Dergisi 66 (2019): 383-418.

Türkkan, Yusuf Sait. Proje Yönetiminde Planlama ve Kontrol Teknikleri. İstanbul: Doğu Kütüphanesi, 2015.

Škomrlj, Nives Ostojić ve Mladen Radujković. "S-Curve Modelling in Early Phases Of Construction Projects." Gradevinar 64 (2012): 647-654.

Zalmai, Mohammed L, Cemil Akcay ve Ekrem Manisal1. "Time-Cost Optimization Using Harmony Search Algorithm In Construction Projects.” Revista De La Construction 18 (2019): 226-237.

5366 Sayılı Kanun, Erişim Tarihi 07 Mart 2021. 
